ARTICLE

DOI: $10.1038 / \mathrm{s} 41467-017-02195-8$

\title{
A 1-phytase type III effector interferes with plant hormone signaling
}

\author{
Doreen Blüher ${ }^{1}$, Debabrata Laha (10) ${ }^{2,3}$, Sabine Thieme ${ }^{1}$, Alexandre Hofer (D) ${ }^{4}$, Lennart Eschen-Lippold ${ }^{5}$, \\ Antonia Masch ${ }^{6}$, Gerd Balcke”, Igor Pavlovic ${ }^{8}$, Oliver Nagel ${ }^{1}$, Antje Schonsky ${ }^{1}$, Rahel Hinkelmann ${ }^{8}$, \\ Jakob Wörner ${ }^{9}$, Nargis Parvin (10 ${ }^{3}$, Ralf Greiner ${ }^{10}$, Stefan Weber ${ }^{9}$, Alain Tissier (1) ${ }^{7}$, Mike Schutkowski ${ }^{6}$, \\ Justin Lee ${ }^{5}$, Henning Jessen (10) ${ }^{4,8}$, Gabriel Schaaf (ib) ${ }^{2,3} \&$ Ulla Bonas ${ }^{1}$
}

Most Gram-negative phytopathogenic bacteria inject type III effector (T3E) proteins into plant cells to manipulate signaling pathways to the pathogen's benefit. In resistant plants, specialized immune receptors recognize single T3Es or their biochemical activities, thus halting pathogen ingress. However, molecular function and mode of recognition for most T3Es remains elusive. Here, we show that the Xanthomonas T3E XopH possesses phytase activity, i.e., dephosphorylates phytate (myo-inositol-hexakisphosphate, InsP6), the major phosphate storage compound in plants, which is also involved in pathogen defense. A combination of biochemical approaches, including a new NMR-based method to discriminate inositol polyphosphate enantiomers, identifies $\mathrm{XopH}$ as a naturally occurring 1-phytase that dephosphorylates Ins $\mathrm{P}_{6}$ at $\mathrm{C} 1$. Infection of Nicotiana benthamiana and pepper by Xanthomonas results in a $X_{o p H}$-dependent conversion of $\operatorname{InsP}_{6}$ to $\operatorname{InsP}_{5}$. 1-phytase activity is required for $\mathrm{XopH}$-mediated immunity of plants carrying the Bs7 resistance gene, and for induction of jasmonate- and ethylene-responsive genes in N. benthamiana.

\footnotetext{
${ }^{1}$ Institute for Biology, Department of Genetics, Martin-Luther University Halle-Wittenberg, Weinbergweg 10, 06120 Halle (Saale), Germany. ${ }^{2}$ Institute of Crop Science and Resource Conservation, Department of Plant Nutrition, University of Bonn, Karlrobert-Kreiten-Strasse 13, 53115 Bonn, Germany. ${ }^{3}$ Center for Plant Molecular Biology, Department of Plant Physiology, Eberhard Karls University Tübingen, Auf der Morgenstelle 32, 72076 Tübingen, Germany.

${ }^{4}$ Department of Chemistry, University of Zurich, Winterthurerstrasse 190, 8057 Zurich, Switzerland. ${ }^{5}$ Department of Stress and Developmental Biology, Leibniz Institute of Plant Biochemistry, Weinberg 3, 06120 Halle (Saale), Germany. ${ }^{6}$ Institute for Biochemistry and Biotechnology, Department of Enzymology, Martin-Luther University Halle-Wittenberg, Kurt-Mothes-Strasse 3, 06120 Halle (Saale), Germany. ${ }^{7}$ Department of Cell and Metabolic Biology, Leibniz Institute of Plant Biochemistry, Weinberg 3, 06120 Halle (Saale), Germany. ${ }^{8}$ Institute of Organic Chemistry, Albert-Ludwigs University Freiburg, Albertstrasse 21, 79104 Freiburg, Germany. ${ }^{9}$ Institute of Physical Chemistry, Albert-Ludwigs University Freiburg, Albertstrasse 21, 79104 Freiburg, Germany. 10 Department of Food Technology and Bioprocess Engineering, Max-Rubner-Institut, Federal Research Institute of Nutrition and Food, Haid-und-Neu-Straße 9, 76131 Karlsruhe, Germany. Doreen Blüher and Debabrata Laha contributed equally to this work. Correspondence and requests for materials should be addressed to H.J. (email: henning.jessen@oc.uni-freiburg.de) or to G.S. (email: gabriel.schaaf@uni-bonn.de) or to U.B. (email: ulla.bonas@genetik.uni-halle.de)
} 
G ram-negative phytopathogenic xanthomonads infect a broad range of plant species causing substantial crop yield losses. Pathogenicity depends in most cases on a conserved type III secretion (T3S) system that translocates effector proteins directly into the plant cell cytosol ${ }^{1}$. The pepper and tomato pathogen Xanthomonas campestris pv. vesicatoria (Xcv, also termed $X$. euvesicatoria ${ }^{2}$ ) encodes more than 30 type III effector (T3E) proteins, designated Xops (Xanthomonas outer proteins), whose collective action in host cells results in bacterial spot disease ${ }^{3,4}$. In resistant plant cultivars, single effectors are recognized by specific immune receptors ${ }^{1}$ often inducing the hypersensitive response (HR), a rapid, local programmed cell death at the infection site which restricts pathogen ingress ${ }^{5}$. While the molecular functions of most T3Es from Xanthomonas are elusive, members of the large family of transcription activatorlike (TAL) effectors act as transcription factors in the plant cell ${ }^{6}$. Other T3Es display enzymatic activities such as the E3 ubiquitin ligase XopL ${ }^{7}$ or AvrBsT, a member of the YopJ/AvrRxv family of acetyltransferases ${ }^{8}$. XopH (also designated AvrBs $1.1^{9}$ ) possesses typical features of dual-specific protein phosphatases, i.e., conserved amino acid residues in the active site ( $\mathrm{P}$ loop) and the WPD loop involved in catalysis ${ }^{10}$ (Fig. 1a). Indeed, XopH dephosphorylates the generic phosphatase substrate pNPP ( $p$-nitrophenyl phosphate) although its activity is weak ${ }^{9}$. Mutation of the $\mathrm{P}$ loop compromises both protein phosphatase activity and the XopH-dependent HR induction in resistant pepper plants 9 .

In this study, we reveal that $\mathrm{XopH}$ dephosphorylates myoinositol-hexakisphosphate (phytate, $\mathrm{Ins}_{6}$ ) in vitro and in vivo.
We provide evidence that XopH's phytase activity is stereoselective for position $\mathrm{C} 1$, is required for $\mathrm{XopH}$-dependent $\mathrm{HR}$ induction in plants carrying the $B s 7$ resistance gene and induces the upregulation of hormone-responsive genes.

\section{Results}

XopH has weak protein phosphatase activity. Using optimized buffer conditions (Supplementary Fig. 1a), we determined essential amino acid residues for XopH-mediated phosphatase activity on pNPP: H239 in the WPD loop and C267 in the active site (Supplementary Fig. 1b). Similar results were obtained with the phosphotyrosine-containing peptide pTyr2, the best substrate out of six tested commercial phosphopeptides (Supplementary Fig. 1c, d). The XopH N-terminal region harbors two proline-rich regions (PRRs), putative peptide/protein interaction sites ${ }^{11}$ that might be involved in substrate recognition (Fig. 1a). Mutations in both PRR motifs compromised catalytic activity albeit less in case of the PRR1 motif. Deletion of the first 77 amino acid residues led to a complete loss of protein phosphatase activity (Supplementary Fig. 1d). To determine XopH substrate specificity, high-density peptide microarrays comprising more than 6000 pTyr peptides were incubated with $\mathrm{XopH}$ and the catalytically inactive C267A variant, respectively (for details see "Methods" section). The top $72 \mathrm{XopH}$ substrates showed $>70 \%$ cleavage by WT XopH and were compared to the negative sample set represented by all peptides displayed on the array. The resulting two-sample logo is shown in Supplementary Fig. 1e. Next, kinetic constants of XopH protein phosphatase activity were determined using three

a

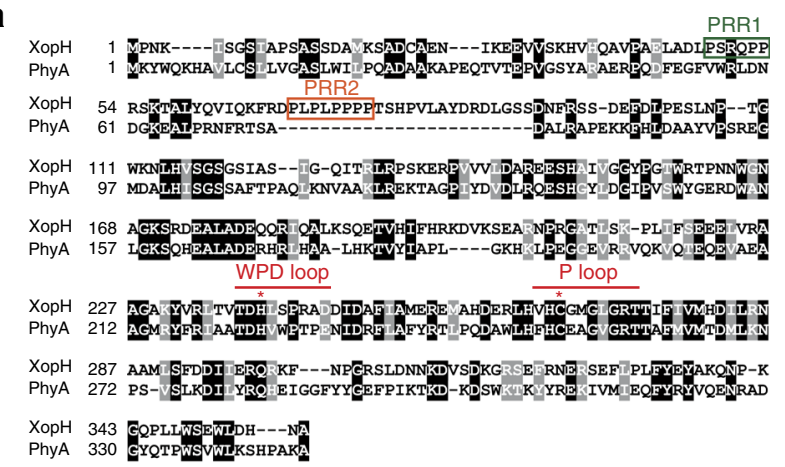

b
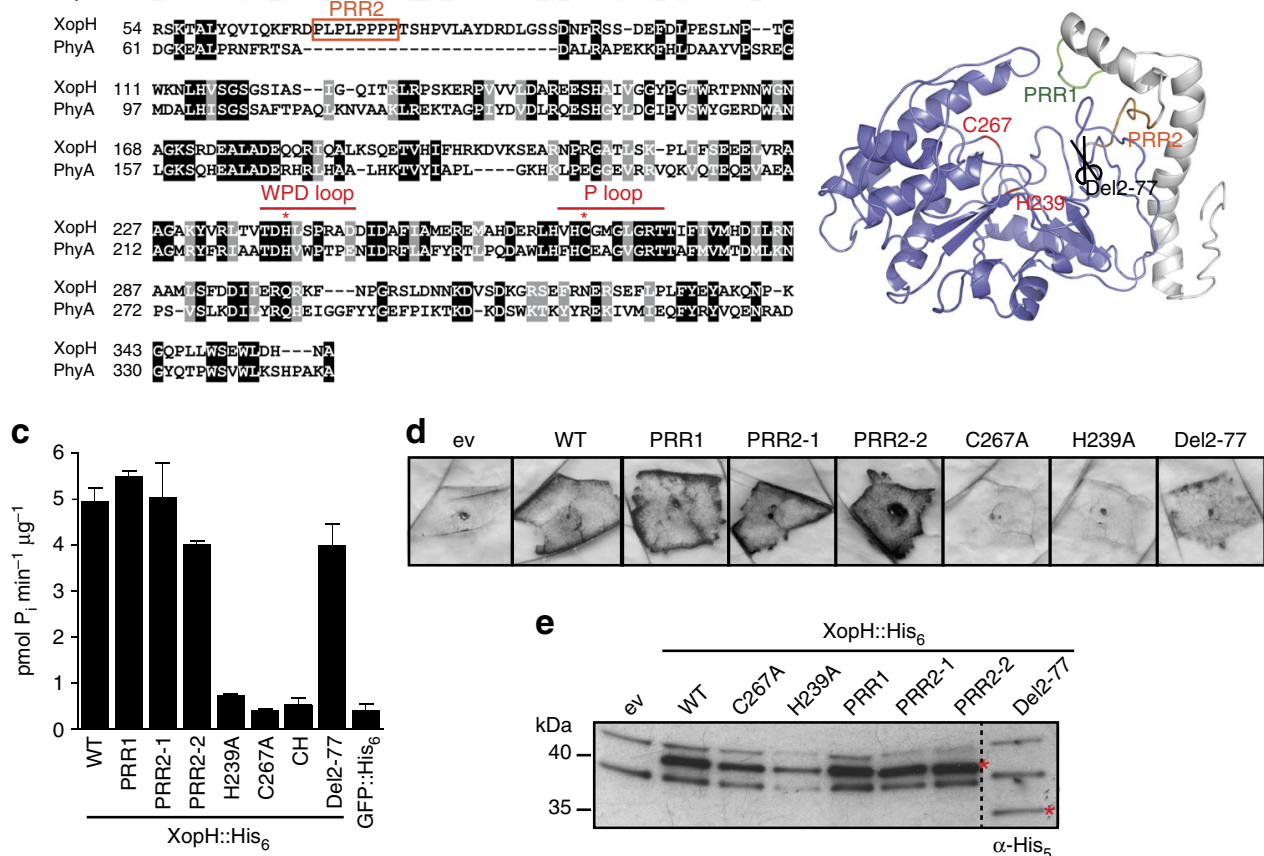

Fig. $1 \mathrm{XopH}$ possesses phytate-degrading activity that is required for HR induction. a Amino acid (aa) sequence alignment of XopH with the Selenomonas ruminantium phytase generated with T-Coffee ${ }^{66}$. Identical and similar aa are shaded black and gray, respectively, using Boxshade ${ }^{67}$. Dashes indicate gaps. Catalytic residues in the WPD and P loops are marked by asterisks. Proline-rich regions (PRRs) are boxed. $\mathbf{b}$ XopH protein structure modeled after the $S$. ruminantium phytase crystal structure (pdb 1U24) using Phyre $2^{14}$, visualized by PyMol ${ }^{68}$. Blue, phytase domain; gray, N-terminal domain (aa 1-77). c InsP 6 dephosphorylation by XopH (WT) and mutants, respectively. PRR1, P48,52,53A; PRR2-1, P69,71A; PRR2-2, P73,74,75,76A; CH, H239A/C267A; Del2-77, deletion of aa 2-77. GFP served as negative control. Values are means of two technical replicates. Error bars indicate s.d. The experiment was performed twice with similar results, using two independent protein preparations each. d HR induction in pepper ECW-70R (Bs7) leaves after Agrobacterium-mediated expression of $\mathrm{XopH}$ and mutant variants. Two days post inoculation (dpi), leaves were bleached in ethanol for better visualization of the HR. e Protein expression, two dpi, in the same plants analyzed in d. Immunoblot signals at expected sizes are marked by asterisks. The experiment was repeated twice with similar results 
Table 1 Catalytic constants of tyrosine phosphatase and phytase activity of $\mathrm{XopH}^{\mathrm{a}}$

\begin{tabular}{|c|c|c|c|c|c|c|}
\hline Substrate & Additive & $V_{\max }\left(\mu \mathrm{mol} \mathrm{L^{-1 }} \min ^{-1}\right)$ & $K_{M}(\mu M)$ & $k_{\text {cat }}\left(s^{-1}\right)$ & $k_{\mathrm{cat}} / K_{\mathrm{M}}\left(\mathrm{M}^{-1} \cdot \mathrm{s}^{-1}\right)$ & $R^{2}$ \\
\hline$\overline{\text { pTyr2 }}$ & $10 \mathrm{mM} \mathrm{NaCl}, 1 \mathrm{mM} \mathrm{MgCl} 2$ & $0.63 \pm 0.16$ & $25.7 \pm 12.2$ & 0.009 & $3.50 \times 10^{2}$ & 0.89 \\
\hline pTyr-chip & $10 \mathrm{mM} \mathrm{NaCl}, 1 \mathrm{mM} \mathrm{MgCl} 2$ & $\begin{array}{l}0.21 \pm 0.12 \\
\left(\mathbf{p} \mathbf{~ m o l ~}_{\mathbf{~ u g}}^{-\mathbf{1}} \mathbf{~ m i n}^{-1}\right)\end{array}$ & $29.7 \pm 3.0$ & 0.028 & $9.42 \times 10^{2}$ & 0.99 \\
\hline $\operatorname{lns} P_{6}$ & $10 \mathrm{mM} \mathrm{NaCl}$ & $110.6 \pm 9.5$ & $138.3 \pm 15.0$ & 45.3 & $3.28 \times 10^{5}$ & 0.99 \\
\hline
\end{tabular}

a
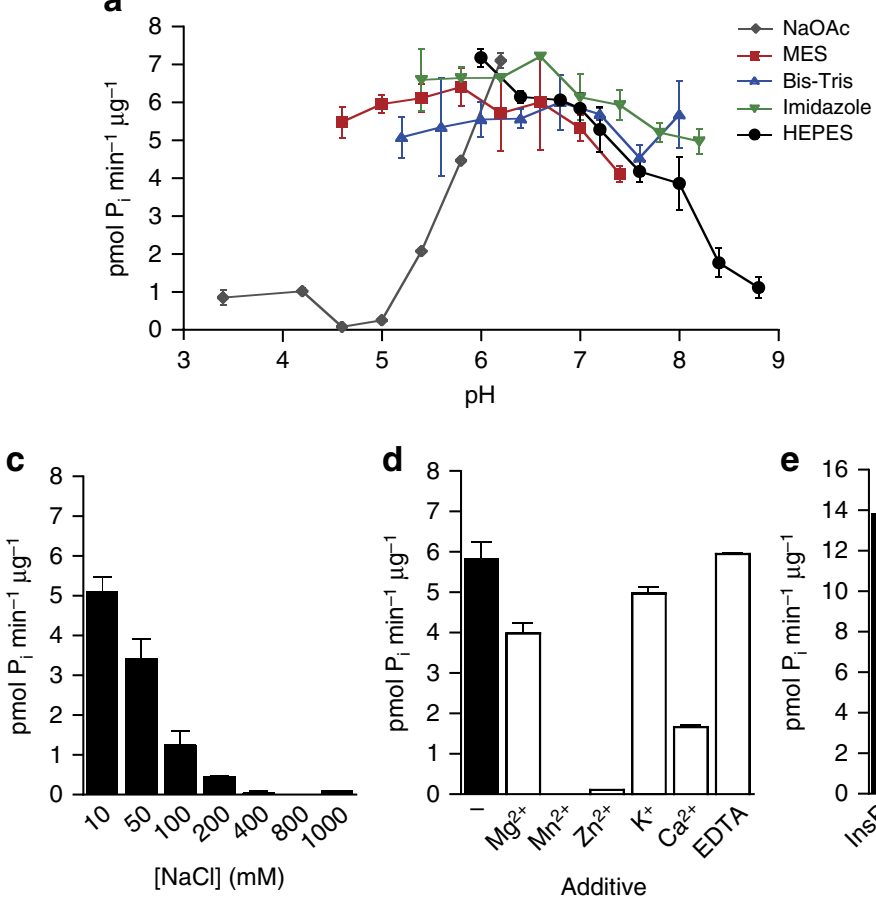

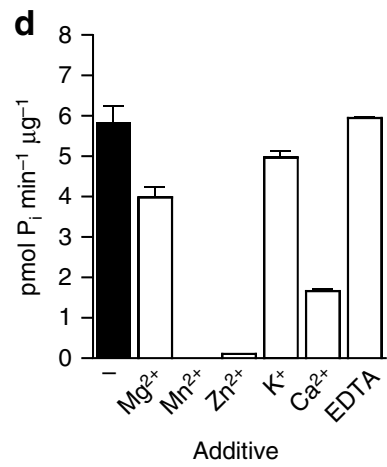

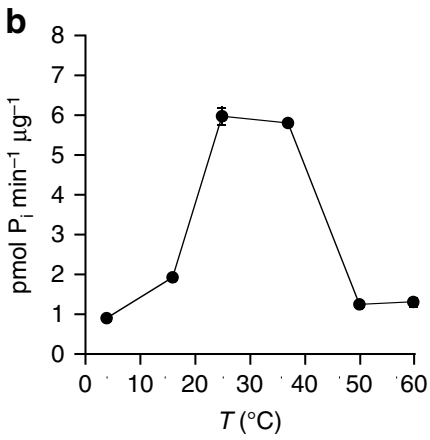

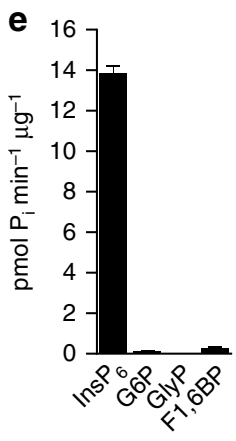

f

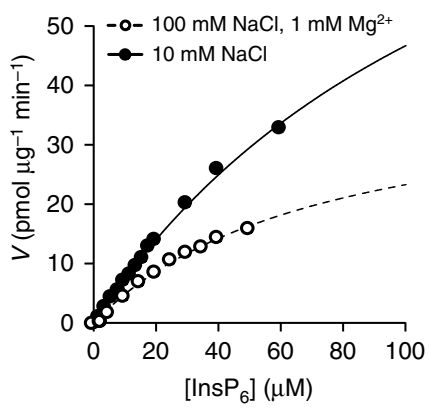

Fig. 2 Characterization of the XopH phytase activity. a XopH activity in presence of $10 \mathrm{mM} \mathrm{NaCl}$ in different buffering systems. $\mathbf{b}$ XopH activity in presence of $100 \mathrm{mM} \mathrm{NaCl}$ and $1 \mathrm{mM} \mathrm{MgCl}_{2}$ at different temperatures $\left(16,25,37,50\right.$, and $\left.60^{\circ} \mathrm{C}\right)$. c XopH activity in buffer with $10-1000 \mathrm{mM} \mathrm{NaCl}$. d XopH activity in absence and presence of $1 \mathrm{mM}$ metal ions or $1 \mathrm{mM}$ EDTA. Reaction buffer contained $10 \mathrm{mM} \mathrm{NaCl}$. e XopH-dependent dephosphorylation of $0.1 \mathrm{mM}$ Ins $\mathrm{P}_{6}$, glucose-6-phosphate (G6P), glycerol phosphate (GlyP), and fructose 1,6-bisphosphate (F1,6BP), respectively. f Kinetics of InsP ${ }_{6}$ dephosphorylation by $\mathrm{XopH}$. Data were fitted to Michaelis Menten equation using KaleidaGraph4.0 (www.synergy.com). $V_{\max }$ and $K_{\mathrm{M}}$ in presence of $100 \mathrm{mM} \mathrm{NaCl}$ and $1 \mathrm{mM}$ $\mathrm{MgCl}_{2}$ (open circles) are $40.0 \pm 5.1 \mathrm{pmol}^{-1} \mathrm{~min}^{-1}$ and $72.9 \pm 13.7 \mu \mathrm{M}$, and in presence of $10 \mathrm{mM} \mathrm{NaCl}$ (closed circles) $110.6 \pm 9.5 \mathrm{pmol}^{-1} \mathrm{~g}^{-1} \mathrm{~min}^{-1} \mathrm{and}$ $138.3 \pm 15.0 \mu \mathrm{M}$. Values are means of two technical replicates. Error bars indicate s.d. The experiments were performed twice with similar results, using two independent protein preparations each

different phosphopeptides and optimized conditions (Supplementary Fig. 1f) in a discontinuous HPLC (high-performance liquid chromatography)-based assay. The randomly selected nonsubstrate from the microarray experiment was not dephosphorylated by XopH. By contrast, $K_{\mathrm{M}}$ values revealed similar affinities for the positive control peptide pTyr2 and the top substrate identified in the peptide microarray ("pTyr-chip"), while $k_{\text {cat }}$ values indicated a threefold higher enzyme efficiency of XopH against "pTyr-chip" (Supplementary Fig. $1 \mathrm{~g}$ and Table 1). Nonetheless, turnover rates were low compared to known protein tyrosine phosphatases ${ }^{12,13}$ raising the possibility that protein dephosphorylation does not represent XopH's primary activity.

XopH degrades phytate. XopH structure predictions using Phyre ${ }^{14}$ revealed a high similarity to the phytase PhyA from the anaerobic bacterium Selenomonas ruminantium ${ }^{15}$ (Fig. 1b). Phytases dephosphorylate myo-inositol hexakisphosphate ( $\operatorname{Ins}_{6}$, synonym.: phytate) to lower phosphorylated myo-inositol derivatives and ortho-phosphate. Phytate is the major phosphate storage compound in plant seeds ${ }^{16}$ and is involved in plant defenses against viral, bacterial, and fungal pathogens ${ }^{17,18}$. We

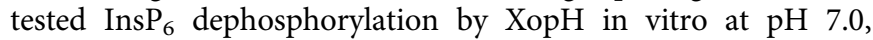
which resembles physiological conditions for $\mathrm{XopH}$ activity because the protein is localized in both the nucleus and cytoplasm of the plant cell ${ }^{19}$. As shown in Fig. 1c, XopH indeed dephosphorylated phytate. To the best of our knowledge, XopH is the first type III effector with phytate-degrading activity to be reported. The WPD loop mutant $\mathrm{H} 239 \mathrm{~A}$ retained residual catalytic activity on $\mathrm{InsP}_{6}$, whereas the $\mathrm{P}$ loop mutant $\mathrm{C} 267 \mathrm{~A}$ and the double mutant H239A, C267A $(\mathrm{CH})$ displayed a complete loss of function (Fig. 1c). Since mutations in the PRR motifs and deletion of the first 77 amino acids of XopH had only minor effects on its activity (Fig. 1c), the N-terminal region flanking the predicted phytase domain appears to be dispensable for phytate dephosphorylation. This is in agreement with the modular structure of 
a

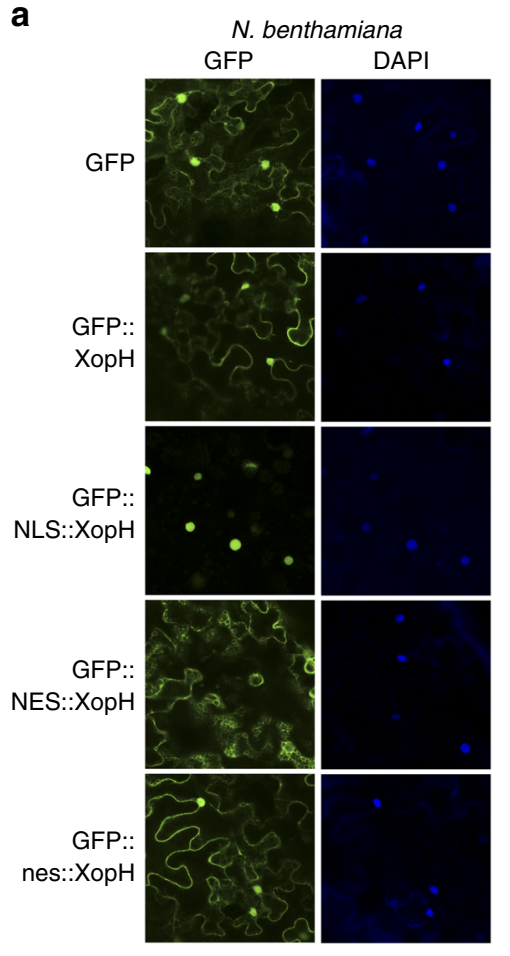

b

ECW-70R (Bs7)
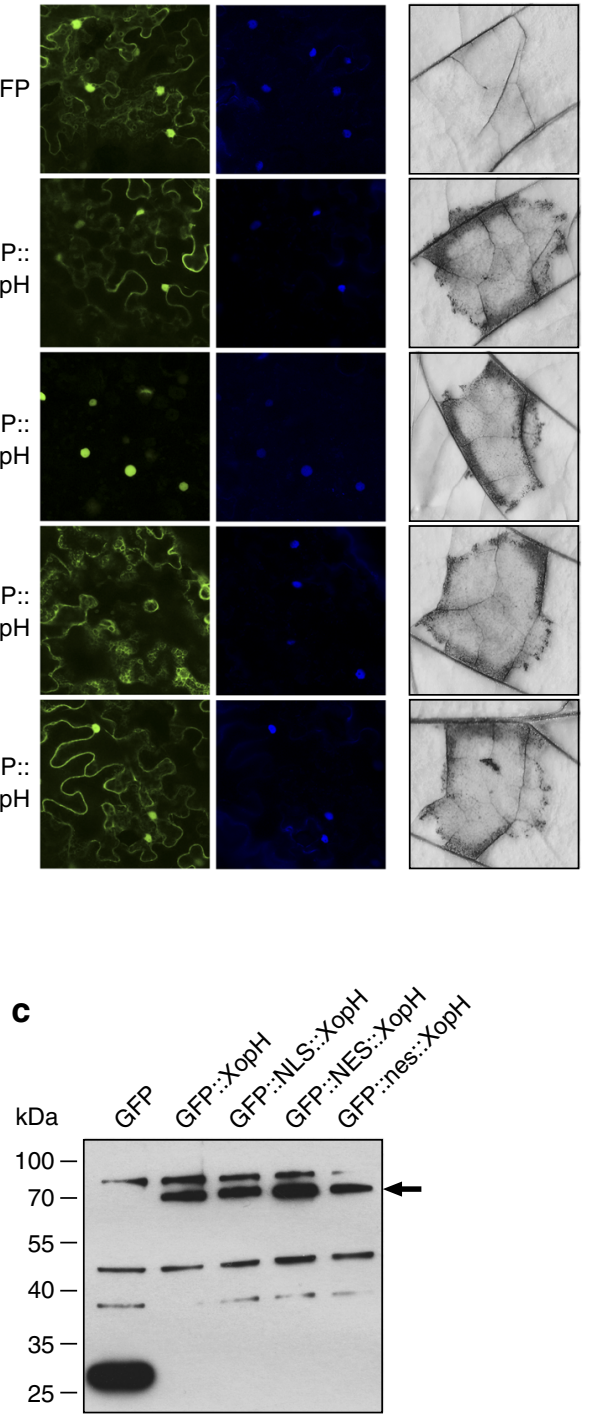
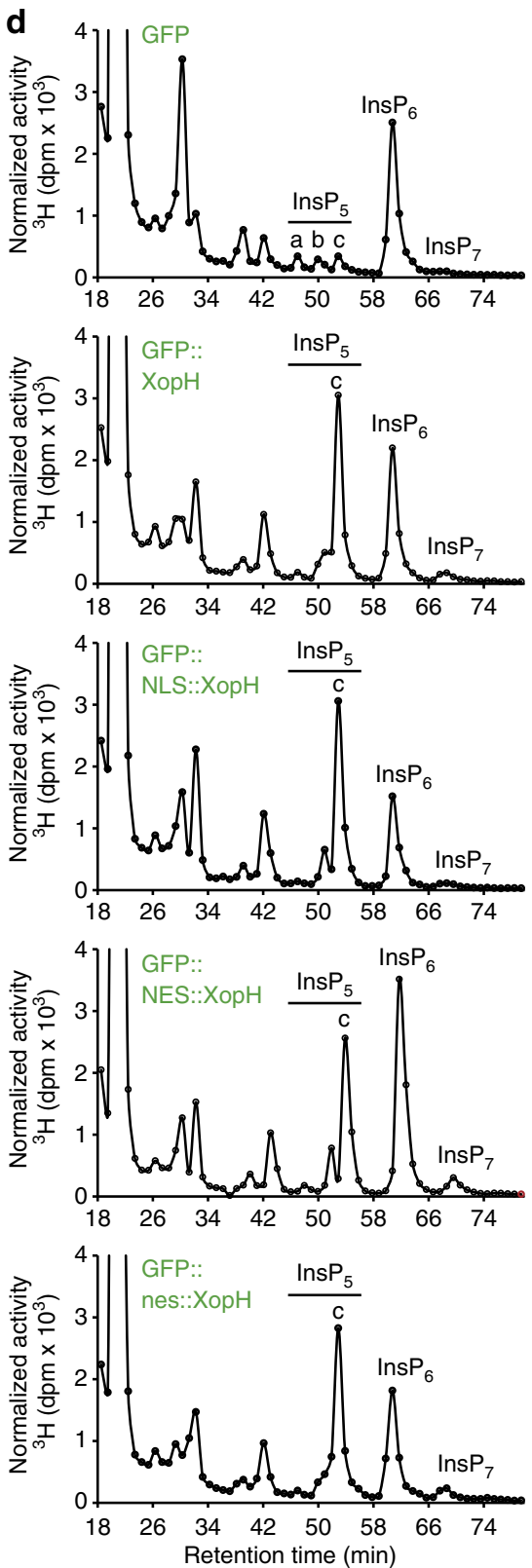

Fig. 3 Both cytoplasmic and nuclear-localized XopH variants are biologically active. a Confocal laser scanning microscopy of $\mathrm{N}$. benthamiana leaves two dpi with Agrobacterium-mediating expression of GFP, $\mathrm{XopH}$, or $\mathrm{XopH}$ fused to a nuclear localization signal (NLS), a nuclear export signal (NES), and a mutated NES (nes), respectively. DAPI (4',6'-Diamidino-2-phenylindole) staining indicates nuclei. b HR induction by XopH and derivatives. The same Agrobacterium strains analyzed in a were infiltrated into leaves of resistant pepper ECW-70R plants. Leaves were harvested two dpi and bleached with ethanol. c Agrobacterium-mediated expression of $\mathrm{His}_{6}$-tagged GFP fusion proteins. Samples were harvested two dpi from the same areas as investigated in a and analyzed by immunoblot. Signals at expected sizes are marked by an arrow. $\mathbf{d}$ SAX-HPLC profiles of extracts from [ $\left.{ }^{3} \mathrm{H}\right]$-myo-inositol-labeled transgenic $\mathrm{N}$. benthamiana seedlings that were inoculated with the Agrobacterium strains described in $\mathbf{a}$. The experiments were repeated twice (a-c) and once (d),

respectively, with similar results

T3Es, which contain a structurally disordered N-terminal region carrying signals for type III-dependent secretion and translocation, and at least one domain for subcellular localization and function in the host cell ${ }^{1}$. Detailed characterization of the XopH phytate-degrading activity revealed a broad $\mathrm{pH}$ activity profile with an optimal $\mathrm{pH}$ range of 5-7 depending on the buffer used, as well as a rather low temperature optimum of $25^{\circ} \mathrm{C}$ compared to other phytases ${ }^{20}$ (Fig. 2a, b). In addition, we tested the effects of ionic strength and different metal ions. $\mathrm{XopH}$ activity is highest at low salt condition (Fig. 2c) and inhibited by $\mathrm{Zn}^{2+}, \mathrm{Mn}^{2+}$, and partially by $\mathrm{Ca}^{2+}$ and $\mathrm{Mg}^{2+}$, but not by the metal ion chelator EDTA (Fig. 2d). There was no detectable XopH-dependent dephosphorylation of the alternative phytase substrates glucose6-phosphate, glycerol phosphate, and fructose 1,6-bisphosphate ${ }^{21}$ suggesting a high substrate specificity of $\mathrm{XopH}$ (Fig. 2e). Using optimized conditions, the specificity constant $k_{\text {cat }} / K_{\mathrm{m}}$ was found to be $3.28 \times 10^{5} \mathrm{M}^{-1} \mathrm{~s}^{-1}$ (Fig. $2 \mathrm{f}$ and Table 1), thus three orders of magnitude higher than the dephosphorylation $k_{\mathrm{cat}} / K_{\mathrm{m}}$ of the best peptide substrate "pTyr-chip" and comparable to the activity of the $S$. ruminantium phytase ${ }^{22}$. We conclude, therefore, that the primary enzymatic activity of $\mathrm{XopH}$ is that of a phytase. Notably, mutant analyses showed that the $\mathrm{XopH}$-induced HR in pepper plants containing the $B s 7$ resistance $(R)$ gene $^{9}$ depends on the phytase but not protein phosphatase activity (Fig. 1d, e). This 
a

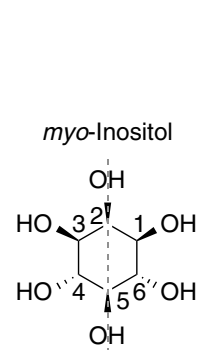

Plane of symmetry position $1 / 3$ and $4 / 6$ identical b
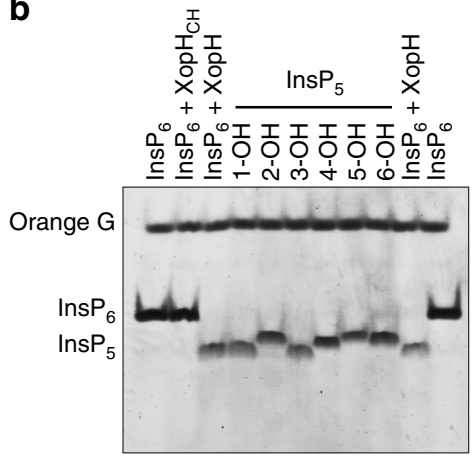

C

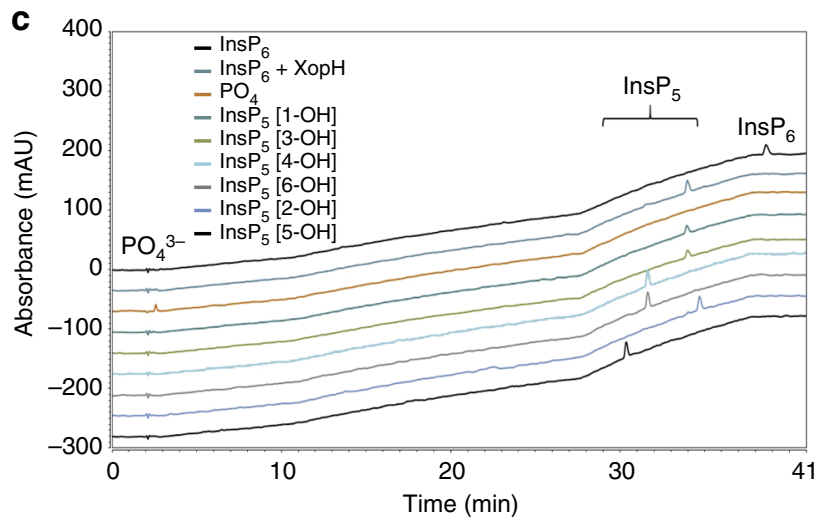

Fig. $4 \mathrm{XopH}$ hydrolyzes $\operatorname{Ins}_{6}$ to $\operatorname{Ins}_{5}[1 / 3-\mathrm{OH}]$. a Structure and symmetry of myo-inositol. b InsP $\mathrm{P}_{6}(10 \mathrm{nmol})$ was incubated with $\mathrm{XopH}_{\text {or }} \mathrm{XopH}_{\mathrm{CH}}$ (catalytically dead). Reaction products were separated by PAGE and stained. InsP $\mathrm{P}_{6}$ and $\mathrm{InsP}_{5}$ isomers $(10 \mathrm{nmol})$ served as controls. Orange $\mathrm{G}$, loading dye. The experiment was repeated twice with similar results. c

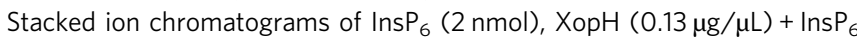
$(2 \mathrm{nmol})$, a phosphate standard $(35 \mathrm{nmol})$ and all $\operatorname{lnsP}_{5}$ isomers $(2 \mathrm{nmol}$ each) eluted on CarboPac PA100: eluent: $0.5 \mathrm{M} \mathrm{HCl}$ and water $(18 \mathrm{M} \Omega$ * $\mathrm{cm})$; detection: post-column reaction with $\mathrm{Fe}^{3+}, \mathrm{UV}, 290 \mathrm{~nm}$, injection volume: $10 \mu \mathrm{L}$

suggests that Bs7 recognizes the consequence of $\mathrm{XopH}$ activity, e.g., changes in myo-inositol polyphosphates, rather than the protein itself. This hypothesis is further corroborated by the fact that changes in the intracellular localization of XopH by fusion to nuclear localization or export signals (NLS, NES) do not significantly affect the HR induction (Fig. $3 \mathrm{a}-\mathrm{c}$ ).

XopH is a 1-phytase. One possibility to classify phytases is based on the number assigned to the carbon atom of the myo-inositol ring at which the first dephosphorylation takes place. Myo-inositol itself is a meso-compound with a plane of symmetry dissecting the 2 and 5 positions (Fig. 4a). This plane of symmetry is retained in $\mathrm{InsP}_{6}$, however, dephosphorylation at either the $1 / 3$ or $4 / 6$ position will create mirror images (enantiomers) by breaking local symmetry (Supplementary Fig. 2). While plants often express 4-phytases that first target the phosphate at $\mathrm{C}$ position 4 , activities of all phytase types have been detected in nature, with the exception of 1 -phytases ${ }^{20}$. Polyacrylamide gel electrophoresis (PAGE) revealed that the XopH reaction product had the same electrophoretic mobility as $\operatorname{Ins}_{5}$ (Fig. 4b); it appears to resist further dephosphorylation by XopH even during extended incubation (up to $24 \mathrm{~h}$, Supplementary Fig. 3a). MALDI-MS and LC-QToF-MS/MS analyses of the XopH reaction product confirmed a main molecular ion peak at 578.9 corresponding to Ins $\mathrm{P}_{5}$ (Supplementary Fig. 3b-d). PAGE analyses in comparison to the six possible InsP $\mathrm{P}_{5}$ isomers revealed that the $\mathrm{XopH}$ cleavage product displays the same electrophoretic mobility as the enantiomeric $1-\mathrm{OH}$ and $3-\mathrm{OH} \mathrm{InsP}_{5}$ isomers (Fig. 4a). Ins $\mathrm{P}_{5}[1 / 3-\mathrm{OH}]$ isomer identity was corroborated by spiking experiments (Supplementary Fig. 4a) and ion chromatography (Fig. 4c and Supplementary Fig. 3e). To elucidate enantiomer identity of the $\mathrm{XopH}$ reaction product, we investigated susceptibility of all InsP isomers to degradation by XopH. Except for $\operatorname{InsP}_{5}[1-\mathrm{OH}]$, all isomers (in particular InsP $\mathrm{P}_{5}[3-\mathrm{OH}]$ ) were readily degraded, albeit the $2-\mathrm{OH}$ and the $6-\mathrm{OH}$ isomer with lower efficiency (Supplementary Fig. 4b). Importantly, resistance of commercial InsP $\mathrm{P}_{5}[1$ $\mathrm{OH}$ ] to $\mathrm{XopH}$-mediated dephosphorylation was not caused by a contaminating phytase inhibitor since addition of $\operatorname{InsP}_{6}$ to the InsP $_{5}[1-\mathrm{OH}] / \mathrm{XopH}$ reaction mixture resulted in rapid hydrolysis of Ins $\mathrm{P}_{6}$ to $\mathrm{InsP}_{5}$ (Supplementary Fig. $4 \mathrm{c}$ ). These results suggest that $\mathrm{InsP}_{5}[1-\mathrm{OH}]$ represents the product of $\mathrm{XopH}$-mediated Ins $_{6}$ hydrolysis.

A new NMR-based method confirms InsP ${ }_{5}[1-\mathrm{OH}]$ as $\mathrm{XopH}$ product. To unambiguously reveal isomer identity of the $\mathrm{XopH}$ cleavage product, we developed a novel method based on nuclear magnetic resonance (NMR) spectroscopy, which can be applied to samples in the presence of buffers and salts that do not interfere with ${ }^{31} \mathrm{P}$-NMR. As briefly discussed above, myo-inositol and phytate are meso-compounds displaying an internal plane of symmetry (Fig. 4a and Supplementary Fig. 2). Thus, for phytate a ${ }^{31} \mathrm{P}-\mathrm{NMR}$ shows two distinct resonances for the phosphates in the 2 and 5 positions, one for the two phosphates in the 1 and 3 positions and another one for the 4 and 6 positions due to internal symmetry. The integrals of the resonances, therefore, display a ratio of 1 (position 2):2 (positions 1 and 3):2 (positions 4 and 6):1 (position 5) (Supplementary Fig. 5a, b). Breaking the symmetry by dephosphorylation in either the $1 / 3$ or $4 / 6$ position will result in distinct signals for every single phosphate, even though they may accidentally have the same chemical shift. Using NMR, one cannot discriminate enantiomers, as they will generate identical resonances in an environment that is achiral (Fig. 5a, top trace). Our method is based on the addition of an enantiopure counter ion that forms one or multiple ion pairs with the inositol phosphate giving rise to diastereomeric salts. This will generate different local environments for the atoms and, therefore, different chemical shifts of the resonances. Such strategies have been developed for other acidic compounds mainly based on ${ }^{1} \mathrm{H}$ $\mathrm{NMR}^{23,24}$. Since phosphates associate tightly with guanidinium groups, we screened several candidate compounds and identified L-arginine amide hydrochloride salt (L-Arg-N) as a suitable counter ion to generate diastereomeric ion pairs with $\mathrm{InsP}_{5}$ even in aqueous buffer. Separate ${ }^{31} \mathrm{P}-\mathrm{NMR}$ measurements of both Ins $_{5}[1-\mathrm{OH}]$ and $\mathrm{InsP}_{5}[3-\mathrm{OH}]$ in the presence of excess L-Arg$\mathrm{N}$ resulted in slightly different shifts for all five peaks (Supplementary Fig. 6). Since ${ }^{31}$ P-NMR chemical shifts are very sensitive to the matrix and especially small changes in $\mathrm{pH}^{25}$, we performed spiking experiments mixing $\mathrm{InsP}_{5}[1-\mathrm{OH}]$ and $\mathrm{InsP}_{5}[3-\mathrm{OH}]$ in different ratios $(1: 1.5,1: 1$, and $1.5: 1)$. While the chiral nonracemic mixture showed four peaks in a ratio of 1:1:2:1, addition of an excess of L-Arg- $\mathrm{N}$ caused a large shift in all resonances and led to resolvable differences for four of the five phosphate signals of both enantiomers (Fig. 5a). This effect was observed in all three different ratios measured. Thus, ${ }^{31} \mathrm{P}-\mathrm{NMR}$ can be used to identify enantiomeric inositol phosphates in the presence of excess L-Arg$\mathrm{N}$ as chiral solvating agent.

We used our method to analyze the XopH hydrolysis product without purification in phosphate-free buffer. Furthermore, commercial InsP $\mathrm{P}_{5}[1-\mathrm{OH}]$ was added to the reaction mixture. The spectrum showed the expected five resonances for Ins $\mathrm{P}_{5}$ and 
a

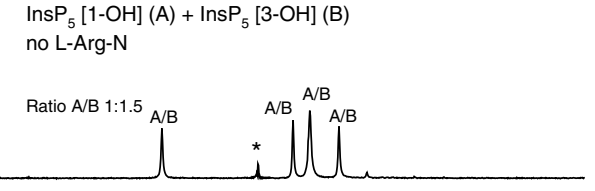

$\operatorname{lns} \mathrm{P}_{5}[1-\mathrm{OH}](\mathrm{A})+\operatorname{InsP}_{5}[3-\mathrm{OH}](\mathrm{B})$ + L-Arg-N
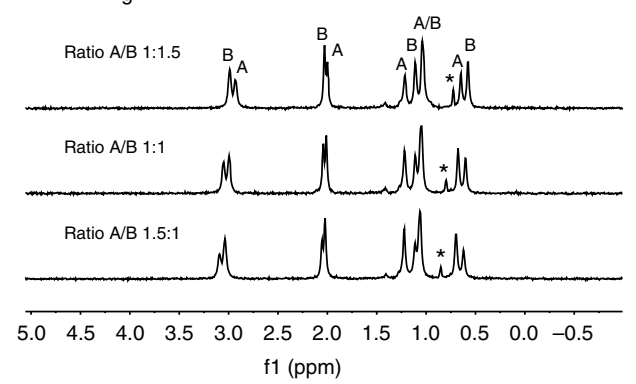

C

Ins $\mathrm{P}_{6}$ dephosphorylation to Ins $\mathrm{P}_{5}$ (A) by $\mathrm{XopH}$

$+\operatorname{InsP}_{5}[1-\mathrm{OH}]\left(\right.$ ratio $\left.\mathrm{A} / \operatorname{lnsP}_{5}[1-\mathrm{OH}] 1.5: 1\right)$

+ L-Arg-N

$95^{\circ} \mathrm{C}, 15 \mathrm{~min}$

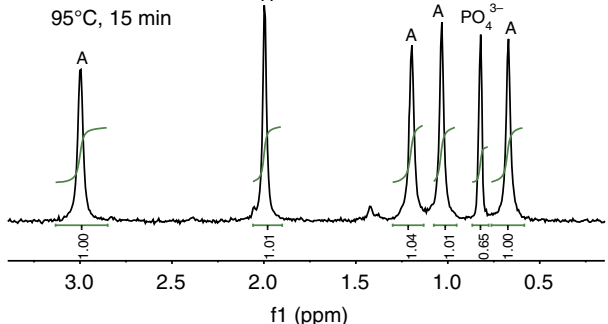

b

InsP $\mathrm{P}_{6}$ dephosphorylation to $\operatorname{InsP}_{5}(\mathrm{~A})$ by $\mathrm{XopH}$

+ InsP $_{5}[1-\mathrm{OH}]$ (ratio A/InsP ${ }_{5}[1-\mathrm{OH})$ 1.5:1]

+ L-Arg-N
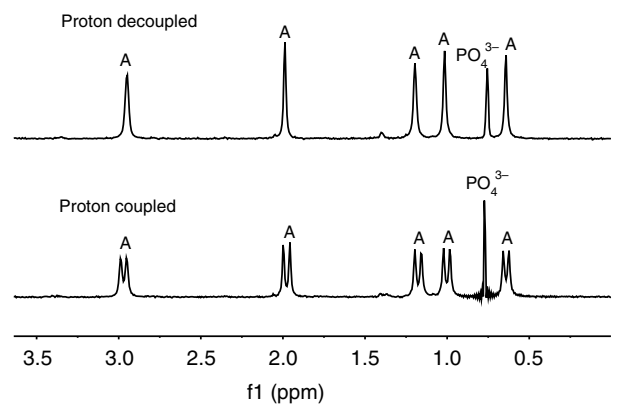

d

Ins $\mathrm{P}_{6}$ dephosphorylation to $\operatorname{Ins}_{5}$ (A) by $\mathrm{XopH}$

$+\mathrm{L}-\mathrm{Arg}-\mathrm{N}$

$95^{\circ} \mathrm{C}, 15 \mathrm{~min}$

$+\operatorname{InsP}_{5}[3-\mathrm{OH}](\mathrm{B})$

Ratio A/B 1.5:1
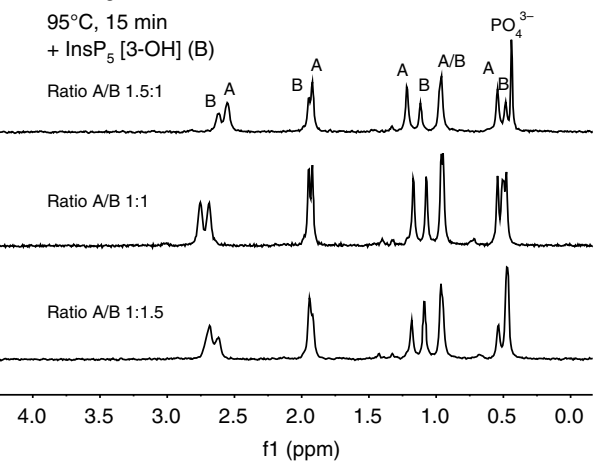

Fig. $5{ }^{31} \mathrm{P}-\mathrm{NMR}$ in the presence of $\mathrm{L}$-arginine amide identifies $\operatorname{Ins}_{5}[1-\mathrm{OH}]$ as the $\mathrm{XopH}$ reaction product. a Upper trace: $\mathrm{Mixture}$ of Ins $\mathrm{P}_{5}[1-\mathrm{OH}](\mathrm{A})$ and Ins $\mathrm{P}_{5}[3-\mathrm{OH}](\mathrm{B})$ in different ratios in ammonium acetate buffer $(\mathrm{pH} 7.1)$ in the absence of L-arginine amide (L-Arg-N). No peak separation was observed and integration gives the expected values 1:1:2:1 (from left to right). Addition of L-Arg-N in excess (ca. 100-fold) leads to separation of the resonances of InsP $\mathrm{P}_{5}[1-\mathrm{OH}](\mathrm{A})$ or InsP $\mathrm{P}_{5}[3-\mathrm{OH}](\mathrm{B})$ in all three different ratios studied (1:1.5, 1:1, and 1.5:1). Asterisks mark an impurity. b Digest of 600 nmol InsP 6 by $\mathrm{XopH}$ in ammonium acetate buffer ( $\mathrm{pH}$ 7.1), spiking with $400 \mathrm{nmol}$ InsP 5 [1-OH] and addition of L-Arg-N in excess (ca. 100-fold). No additional peaks can be seen in a proton-decoupled spectrum (upper trace). A proton-coupled spectrum identifies all resonances belonging to inositol-bound phosphates (A). $\mathbf{c}$ Digest of $600 \mathrm{nmol}$ InsP $\mathrm{P}_{6}$ by XopH, spiking with $\mathrm{InsP}_{5}[1-\mathrm{OH}]$ and addition of L-Arg- $\mathrm{N}$ in excess (ca. 100-fold). The mixture was heated to $95^{\circ} \mathrm{C}$ for 15 min to denature residual $\mathrm{XopH}$. Integration identifies the phosphate resonance (expected ratio is 1.0:0.6) and shows that no decomposition after boiling takes place. $\mathbf{d}$ XopH digest of $600 \mathrm{nmol}$ and excess L-Arg-N (ca. 100 -fold) boiled at $95^{\circ} \mathrm{C}$ for $15 \mathrm{~min}$. Subsequent addition of InsP $\mathrm{P}_{5}$ [3-OH] (B) in different ratios leads to appearance of new resonances

an additional resonance for phosphate that was easily identified by (i) recording of a proton-coupled spectrum (Fig. 5b, lower trace) and (ii) integration of the peaks (Fig. 5c). The protoncoupled spectrum showed peak splitting (doublets) only for the phosphates bound to the inositol scaffold, whereas in $\mathrm{PO}_{4}{ }^{3-}$ no bound protons were available for coupling. The spiked spectrum also showed that the integral of $\mathrm{PO}_{4}{ }^{3-}$ was smaller than those of the other resonances, as only $\mathrm{InsP}_{5}[1-\mathrm{OH}]$ was added. Heating of the sample to destroy residual $\mathrm{XopH}$ activity did not cause decomposition of $\mathrm{InsP}_{5}$ (Fig. 5c). Next, a XopH digest obtained as described above was inactivated at $95^{\circ} \mathrm{C}$ and then spiked with Ins $_{5}[3-\mathrm{OH}]$ in different ratios in presence of an excess of L-Arg$\mathrm{N}$. As with the Ins $\mathrm{P}_{5}[1-\mathrm{OH} / 3-\mathrm{OH}]$ mixture, a clear separation of four of the five phosphate signals was achieved and easily assigned by peak intensity (Fig. 5d). Notably, addition of InsP $\mathrm{P}_{5}$ [1$\mathrm{OH}$ ] under the same conditions did not lead to the separation of any of the resonances (Fig. 5c). In combination with the PAGE and IC analyses, we conclude that the $\mathrm{XopH}$ reaction product corresponds to InsP $\mathrm{P}_{5}[1-\mathrm{OH}]$. Hence, $\mathrm{XopH}$ is the first naturally occurring 1-phytase.

XopH leads to InsP $P_{5}$ accumulation in vivo. To analyze the consequences of $\mathrm{XopH}$ phytate-degrading activity in vivo, we compared the composition of myo-inositol polyphosphates in Saccharomyces cerevisiae ectopically expressing XopH or the phytase-inactive $\mathrm{XopH}_{\mathrm{C} 267 \mathrm{~A}}$ mutant, by strong anion exchange (SAX) HPLC, a method that by itself does not allow to discriminate between enantiomers in the absence of chiral selectors. Ectopic expression of $\mathrm{XopH}$ in yeast caused a strong reduction of InsP $_{6}$ and a robust accumulation of Ins $\mathrm{P}_{5}$ with the chromatographic mobility of $\mathrm{InsP}_{5}[1 / 3-\mathrm{OH}]$ (Fig. 6). Furthermore, an increase in one $\mathrm{InsP}_{4}$ and one $\mathrm{InsP}_{3}$ species, both of unknown stereochemistry, was detected. By contrast, expression of the catalytically dead mutant $\mathrm{XopH}_{\mathrm{CH}}$ did not cause significant changes in the HPLC profile as compared to the control (Fig. 6).

In agreement with a role of $\mathrm{XopH}$ in $\mathrm{InsP}_{6}$ dephosphorylation, transgenic Nicotiana benthamiana plants constitutively expressing $x o p H$ showed a robust accumulation of $\operatorname{Ins}_{5}[1 / 3-\mathrm{OH}]$ at the cost of InsP $_{6}$ (Fig. 7a and Supplementary Fig. 7). Altered localization of $\mathrm{XopH}$ to only nucleus or cytoplasm had no major effect on its ability to hydrolyze InsP $_{6}$ (Fig. 3d), a small molecule likely to diffuse freely between nucleo- and cytoplasm. Given the biochemical data described above, the observed $\operatorname{Ins}_{5 c}$ isomer likely represents Ins $\mathrm{P}_{5}[1-\mathrm{OH}]$. To test this idea, Ins $\mathrm{P}_{5 \mathrm{c}}$ and $\mathrm{InsP}_{6}$ were purified from $\left[{ }^{3} \mathrm{H}\right]$-myo-inositol-labeled $x o p H-$ and GFPtransgenic $N$. benthamiana seedlings, subjected to digest by XopH 

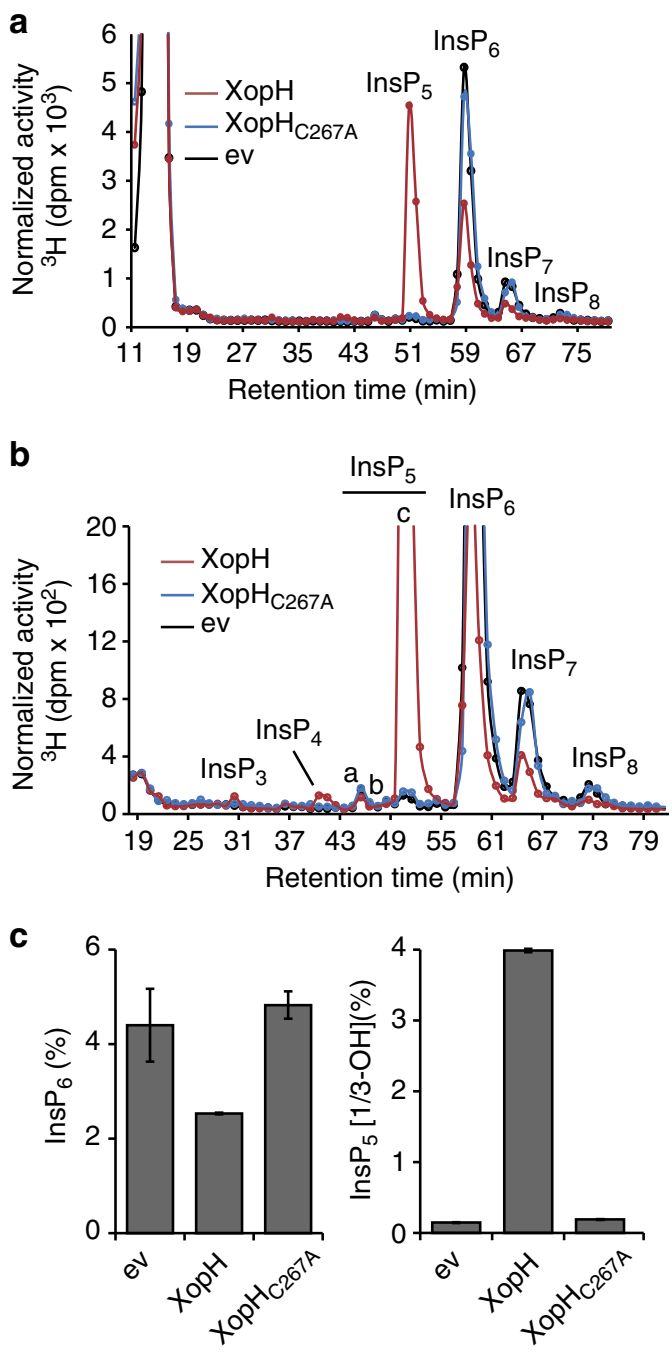

Fig. $6 \mathrm{XopH}$ changes Ins $\mathrm{P}_{\mathrm{x}}$ contents in yeast. a HPLC profile of extracts from yeast transformants labeled with $\left[{ }^{3} \mathrm{H}\right]$-myo-inositol. ev empty vector. Based on published chromatographic mobilities ${ }^{69}, \operatorname{InsP}_{5 a}$ represents $\operatorname{lns} \mathrm{P}_{5}$ $[2-\mathrm{OH}], \operatorname{lns} \mathrm{P}_{5 b}$ represents $\operatorname{InsP}_{5}[4 / 6-\mathrm{OH}]$, and $\operatorname{lns} \mathrm{P}_{5 c}$ represents $\operatorname{Ins} \mathrm{P}_{5}$ $[1 / 3-O H]$. The isomeric natures of $\operatorname{Ins}_{3}, \operatorname{lnsP}_{4}, \operatorname{InsP}_{7}$, and $\operatorname{lns} \mathrm{P}_{8}$ are unknown. $\mathbf{b}$ Zoom-in on the HPLC profile. c Relative amounts of InsP $\mathrm{P}_{6}$ and $\operatorname{Ins}_{5 c}$ in the yeast transformants. Error bars indicate s.e.m. The experiment was repeated independently with similar results

and separated by SAX-HPLC. Under these conditions, XopH did not further dephosphorylate Ins $\mathrm{P}_{5 c}$, whereas purified $\mathrm{InsP}_{6}$ was readily degraded, thus increasing the $\mathrm{Ins}_{5 \mathrm{c}}$ peak (Fig. $7 \mathrm{~b}$ and Supplementary Fig. 8). This is consistent with the XopHdependent Ins $\mathrm{P}_{5 c}$ corresponding to $\operatorname{InsP}_{5}[1-\mathrm{OH}]$ which, in contrast to all other $\mathrm{InsP}_{5}$ isomers, is resistant to $\mathrm{XopH}$-mediated dephosphorylation (see above). The observation that $\mathrm{InsP}_{5}$, presumably the Ins $\mathrm{P}_{5}[1-\mathrm{OH}]$ enantiomer, strongly accumulates and is not degraded further by plant enzymes implies that suitable endogenous phosphatases might be absent in $N$. benthamiana.

To investigate whether InsP $\mathrm{P}_{5}[1-\mathrm{OH}]$ accumulates in the plant during natural infection, i.e., after XopH translocation via the $\mathrm{Xcv}$ T3S system, we inoculated the Xcv WT strain, a $x o p H$ frameshift mutant and the complemented mutant into $N$. benthamiana. InsP $_{6}$ and InsP $_{5}$ contents were determined by PAGE after titanium oxide $\left(\mathrm{TiO}_{2}\right)$ bead enrichment. Although N. benthamiana is not a natural host of $X c v$, we recently showed that this is solely due to the recognition of a single T3E, XopQ, which triggers a defense reaction and prevents bacterial growth ${ }^{26}$.
Deletion of $x o p Q$ turns $X c v$ strain 85-10 into a N. benthamiana pathogen that grows in the tissue and elicits typical disease symptoms, i.e., water-soaked lesions ${ }^{26}$. As shown in Fig. 7c, inoculation of 85-10 $\Delta x o p Q$ ("WT") induced a slight decrease in the plant's Ins $\mathrm{P}_{6}$ content and an additional $\mathrm{InsP}_{5}$ signal. By contrast, leaves inoculated with the respective $x \circ p H$ frameshift mutant (85-10 $\Delta x o p Q \_$fs- $\left.x o p H\right)$ contained even more InsP $_{6}$ than mock-infiltrated plant tissue and no Ins $\mathrm{P}_{5}$ in detectable amounts. 85-10 $\Delta x o p Q \_$fs- $x o p H$ was complemented by re-integration of $x o p H$ into the genome (Fig. $7 \mathrm{c}$ ).

In addition, we analyzed XopH-dependent changes in $\mathrm{InsP}_{6}$ and Ins $\mathrm{P}_{5}$ contents in the $X c v$-pepper system. Although Ins $\mathrm{P}_{5}$ was barely detectable in pepper, there was a clear Ins $\mathrm{P}_{6}$ decrease after inoculation of strains expressing $\mathrm{XopH}$, but not the inactive $\mathrm{XopH}_{\mathrm{CH}}$ mutant version (Supplementary Fig. 9). Notably, the $x o p H$ frameshift mutant was complemented by expression of $\mathrm{XopH}_{\text {Del77 }}$ confirming that the phytase, and not the protein phosphatase, activity is responsible for the observed $\mathrm{InsP}_{6}$ decrease. Leaf tissue inoculated with a T3S-deficient strain $(\Delta h r c N)$ showed a similar InsP $_{6}$ content as that infected with the $x o p H$ mutant. This suggests that $\mathrm{XopH}$ is the only T3E in $\mathrm{Xcv}$ strain $85-10$, which significantly affects phytate levels.

XopH affects plant hormone pathways. Plant hormone signaling pathways can involve Ins $\mathrm{P}_{\mathrm{x}}$ co-factors, as was suggested for auxin and jasmonate (JA) signal transduction ${ }^{27-29}$, and might, therefore, be affected by changes in the $\operatorname{InsP}_{\mathrm{x}}$ homeostasis. XopH expression in $N$. benthamiana leaves caused a strong concomitant reduction of inositol pyrophosphates Ins $\mathrm{P}_{7}$ and Ins $\mathrm{P}_{8}$ (Fig. $7 \mathrm{a}$ and Supplementary Fig. 7). The latter is required for jasmonate perception, most likely by inducing an allosteric switch of the jasmonate receptor complex ${ }^{18,29}$. We analyzed the influence of XopH expression on transcript abundance of JA-responsive genes in $N$. benthamiana leaves without or $20 \mathrm{~min}$ after wounding. qRT-PCR analysis revealed that XopH led to a slightly reduced $M Y C 2$ expression, but induced PR1b, PR4, and PI-II (Fig. 8a, b), which were used as general JA marker genes in previous studies in solanaceous plants ${ }^{30,31}$. Weaker induction was observed with

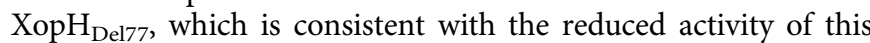
$\mathrm{XopH}$ variant (Fig. 1c, d) and demonstrates that the phytase, and not the protein phosphatase, activity is required for gene induction (Fig. 8a, b).

Notably, PR1b, PR4, and PI-II genes are not only JA responsive, but also ethylene (ET) responsive ${ }^{32,33}$, suggesting that $\mathrm{XopH}$ might affect the ET pathway. Consistent with this idea, transgenic $N$. benthamiana plants constitutively expressing xopH were significantly smaller than transgenic GFP control plants of the same age and showed signs of early senescence (Supplementary Fig. 10). We performed virus-induced gene silencing of EIN2 and EBF1 encoding a positive and negative regulator of the ET pathway, respectively ${ }^{34}$, in $N$. benthamiana and analyzed the effect on XopH-mediated induction of PR1b, PR4, and PI-II. In addition, we silenced COI1, the positive master regulator of the JA pathway $^{35}$. A GFP silencing construct served as control. While COI1 silencing revealed no obvious involvement of the JA pathway in XopH-dependent gene induction, silencing of ET pathway components (especially EIN2) suppressed the upregulation of PR4 and PI-II, but not PR1b (Fig. 8c, d).

\section{Discussion}

$\mathrm{XopH}$ is a T3E with a novel phytate-degrading activity, which we demonstrated in vitro and in planta. Using a combination of different digestion experiments of chemically pure inositol polyphosphates and an NMR-based method to discriminate $\mathrm{InsP}_{5}$ 
isomers, we identified $\mathrm{XopH}$ as the prototype of a new class of phytases initiating $\mathrm{InsP}_{6}$ dephosphorylation at $\mathrm{C}$ position 1 . Thus, $\mathrm{XopH}$ belongs to the relatively small number of Xanthomonas T3Es with identified biochemical activities: the large group of TAL effectors and T3Es with uridylyltransferase (AvrAC), acetyltransferase/cysteine protease (YopJ/AvrRxv family), SUMO protease (XopD), and ubiquitin ligase activity (XopL) ${ }^{1}$.
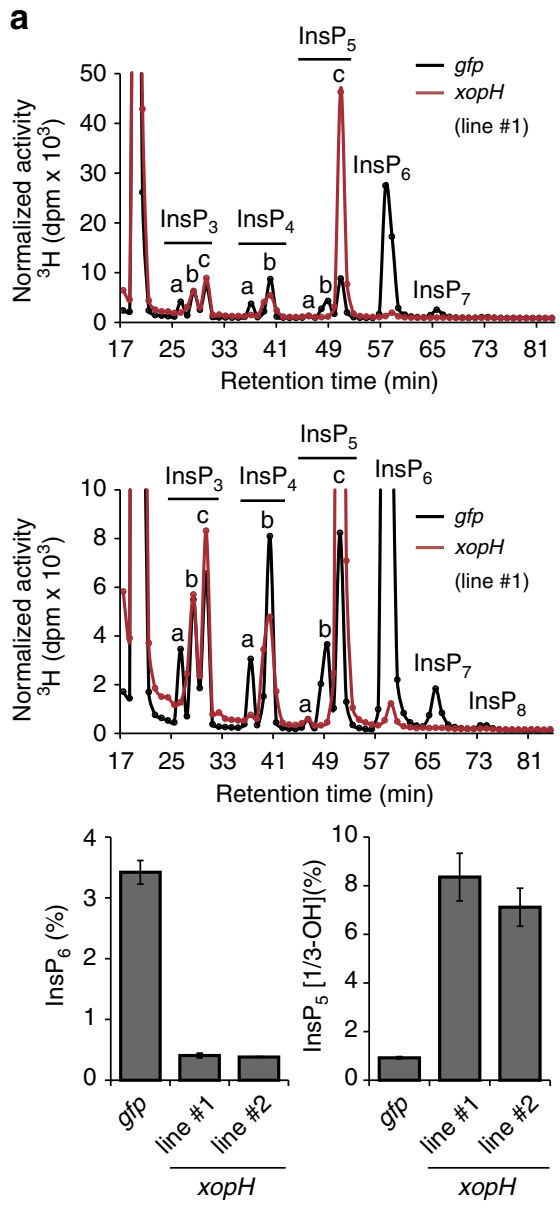

C

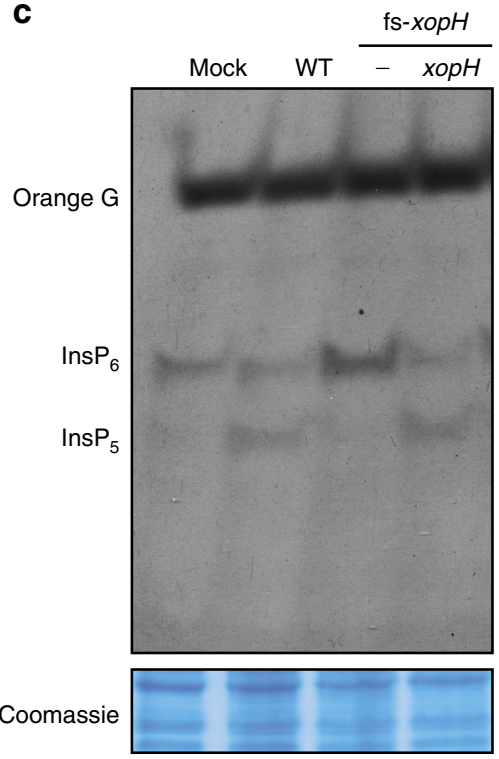

Our mutant analyses indicate that the phytase and not the protein phosphatase activity is relevant for XopH's biological activities, i.e., HR elicitation in the host plant pepper (Fig. 1d) and gene induction in N. benthamiana (Fig. 8a). In this respect, $\mathrm{XopH}$ has a different physiological function than its homolog HopAO1 (formerly termed HopPtoD2; 25\% identical to XopH) from Pseudomonas syringae pv. tomato. HopAO1 was reported to

b
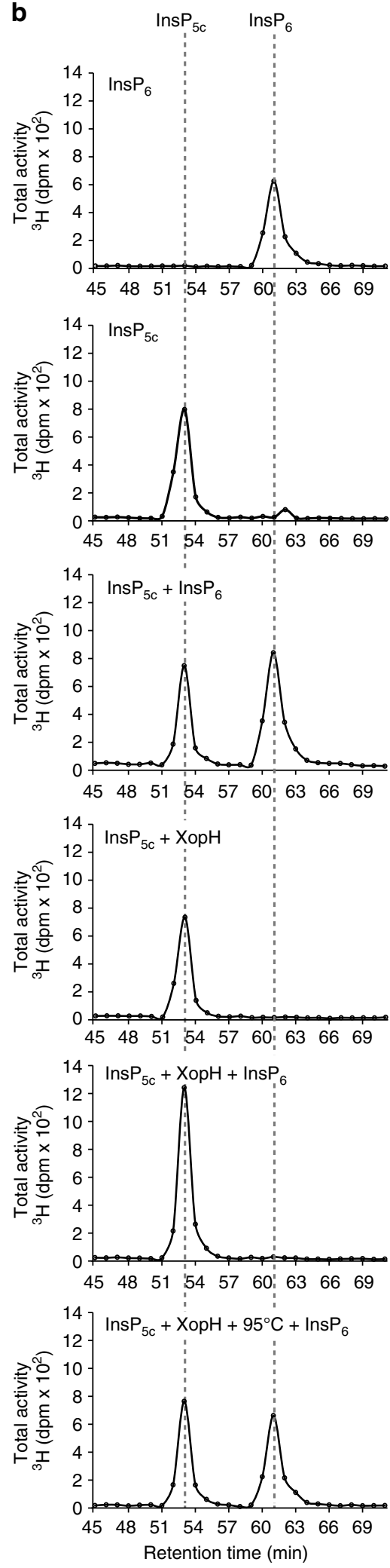
reduce tyrosine phosphorylation of the PAMP receptor EFR, after recognition of the elf18 peptide from bacterial elongation factor $\mathrm{Tu}$, thus preventing immune responses ${ }^{36}$. By contrast, $\mathrm{XopH}$ does not inhibit elf18-inducible gene expression ${ }^{19}$. Furthermore, membrane proteins, such as EFR (or other proteins that do not enter the nucleus), are unlikely targets of $\mathrm{XopH}$, because nuclear or cytoplasmic XopH variants exhibit similar HR-inducing activities in resistant pepper plants (Fig. 3), and both virulence and HR-inducing activities of T3Es are often connected (see below). Notably, we found that HopAO1 degraded phytate in vitro but, in contrast to XopH, to lower phosphorylated myoinositol derivatives (Supplementary Fig. 11). In conclusion, this suggests different activities for XopH and HopAO1.

The fact that only the phytase domain of XopH is essential for HR induction suggests that Bs7 recognizes the product of the enzyme reaction, i.e., Ins $\mathrm{P}_{5}[1-\mathrm{OH}]$, or changes caused by altered inositol polyphosphate homeostasis rather than the $\mathrm{XopH}$ protein itself. This hypothesis is supported by the fact that $\mathrm{XopH}$ variants solely localizing to the nucleus or the cytoplasm of the plant cell have the same HR-inducing activity as the WT protein, which correlates with similar phytase activities (Fig. 3). Indeed, most $\mathrm{R}$ proteins recognize their cognate T3Es indirectly by detecting effector-triggered changes in plant targets (guard model) or nonfunctional target mimics (decoy model) $)^{1}$. Notably, the molecules targeted by T3Es are usually proteins or, as in case of TAL effectors, DNA sequences and not low-molecular substances like inositol polyphosphates.

What are the consequences of phytate dephosphorylation and InsP $_{5}[1-\mathrm{OH}]$ accumulation for susceptible plant cells and the bacterial pathogen, which lives in the intercellular spaces? One possibility is that XopH liberates phosphate from the plant tissue to improve the nutritional status of the pathogen. A role in phosphate acquisition from the extracellular milieu has been reported for the putative phytase PhyA secreted by the rice pathogen $X$. oryzae pv. oryzae. PhyA $\mathrm{X}_{\text {Xoo }}$ enhances bacterial growth in medium with phytate as sole phosphate source and is required for virulence ${ }^{37}$. Another scenario supported by our qRTPCR data is that XopH interferes with plant hormone pathways, probably by affecting the abundance of potential co-factors. According to this hypothesis, our data give a first hint that $\operatorname{Ins} P_{\mathrm{x}}$ co-factors are also involved in the ET pathway. Since ET acts synergistically with JA to regulate resistance against necrotrophic pathogens ${ }^{34}$, stimulation of the ET pathway might be beneficial to hemibiotrophic bacteria like $X c v$. Furthermore, bacterial dispersal may benefit from ET functions in disease development at later infection stages ${ }^{38}$. Notably, XopH has been recently reported to promote disease symptom formation on tomato ${ }^{19}$. A third model is that XopH compromises plant defense mechanisms by degradation of $\mathrm{InsP}_{6}$, which has been suggested to play a role in resistance against a wide variety of pathogens ${ }^{17,18}$. XopH might sequester Ins $\mathrm{P}_{6}$ by degrading it to an $\mathrm{InsP}_{5}$ isomer, which is not easily metabolized by the plant (as shown above) and accumulates. Indeed, XopH has been recently shown to inhibit defense reactions, e.g., callose deposition, in Arabidopsis ${ }^{19}$. A similar strategy is imaginable for the phytase LppA from the human pathogen Legionella pneumophila: while the product of LppA activity is unknown, LppA has been shown to be translocated via the type IV secretion system and to counteract intracellular bacterial growth restriction by phytate ${ }^{39}$. By taking advantage of an enantiomer-specific Dictyostelium InsP $\mathrm{P}_{5}[3-\mathrm{OH}]$ kinase activity, the InsP $\mathrm{P}_{5 c}$ species in mung bean seedlings was proposed to largely consist of InsP $\mathrm{P}_{5}[1-\mathrm{OH}]^{40}$. Future work will have to clarify isomer identity and physiological role of the endogenous (XopHindependent) InsP $\mathrm{P}_{5 c}$ species in $N$. benthamiana and pepper. Because $\mathrm{InsP}_{6}$ is ubiquitous in eukaryotes and is known to have critical roles in these systems ${ }^{16}$, we believe that the mechanism employed by Xanthomonas could be a common strategy of host immune system avoidance for bacteria and other pathogens. Therefore, our discovery might provide the basis for the development of new strategies to overcome or attenuate crop disease caused by bacterial pathogens.

In addition, the novel activity of XopH reported here adds to the molecular toolbox for future biotechnological manipulation of phytate levels. Because of its high affinity for minerals including iron and zinc ions, phytate is considered an antinutrient for humans and monogastric animals (swine, poultry, and fish), all of which lack the ability to significantly degrade phytate ${ }^{20}$. Hence, phytases are economically important enzymes that are widely used to improve phosphate and mineral availability in animal feed and to reduce phosphate excretion by animals ${ }^{20}$. Furthermore, the novel 1-phytase specificity of XopH gives access to a new set of inositol phosphate isomers. InsP $\mathrm{P}_{5}[1-\mathrm{OH}]$ and its derivatives generated by other phosphatases will, for instance, prove useful for the future characterization of new phytases and phosphatases.

\section{Methods}

Plant material and inoculations. Nicotiana benthamiana and pepper (Capsicum annuum) cultivar ECW-70R $(B s 7)^{9}$ plants were grown in the greenhouse under standard conditions (day and night temperatures of $23^{\circ} \mathrm{C}$ and $19^{\circ} \mathrm{C}$, respectively, for $N$. benthamiana, and $25^{\circ} \mathrm{C}$ and $19^{\circ} \mathrm{C}$ for pepper, with $16 \mathrm{~h}$ light and $40-60 \%$ humidity). For in planta protein expression, mature leaves of 5- to 7-week-old plants were inoculated with Agrobacterium tumefaciens adjusted to $\mathrm{OD}_{600}=0.8$ in infiltration medium (10 mM MES pH 5.5, $10 \mathrm{mM} \mathrm{MgCl}_{2}, 150 \mu \mathrm{M}$ acetosyringone) using a needleless syringe. $X c v$ was inoculated (in $10 \mathrm{mM} \mathrm{MgCl}_{2} ; \mathrm{OD}_{600}=0.1$ or 0.02 ) into leaves of 6-week-old pepper or $N$. benthamiana plants using a needleless syringe. Inoculated pepper plants were transferred to a Percival growth chamber (Percival Scientific, Perry, USA).

\begin{abstract}
Bacterial strains and growth conditions. Escherichia coli BL21(DE3) (Agilent Technologies Inc., Santa Clara, USA) and TOP10 (Life Technologies GmbH, Darmstadt, Germany) were cultivated at $37^{\circ} \mathrm{C}$ in LB (lysogeny broth) medium ${ }^{41}$, A. tumefaciens GV $3101^{42}$ and derivatives at $30^{\circ} \mathrm{C}$ in YEB (yeast extract broth) and $X c v$ strain $85-10^{3}$ and derivatives on NYG (nutrient yeast glycerol) agar plates ${ }^{43}$ supplemented with appropriate antibiotics. Plasmids were introduced into $E$. coli and A. tumefaciens by electroporation, and into $X c v$ by conjugation using pRK2013 as helper plasmid in triparental matings ${ }^{44}$.
\end{abstract}

Fig. 7 XopH causes Ins $\mathrm{P}_{5}$ accumulation in planta. a Upper panel: HPLC profiles of extracts from transgenic $N$. benthamiana leaves, labeled with [ $\left.{ }^{3} \mathrm{H}\right]-\mathrm{myo}^{-}$ inositol. Based on published chromatographic mobilities ${ }^{69}, \operatorname{lnsP}_{5 a}$ represents $\operatorname{lns}_{5}[2-\mathrm{OH}]$, Ins $P_{5 b}$ represents $\operatorname{lns} \mathrm{P}_{5}[4 / 6-\mathrm{OH}]$, and InsP $\mathrm{P}_{5 \mathrm{c}}$ represents $\operatorname{Ins}_{5}$

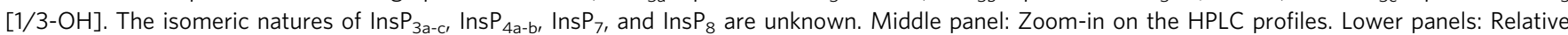
amounts of $\operatorname{Ins}_{6}$ and $\operatorname{InsP}_{5 c}$ in N. benthamiana expressing gfp and two independent lines expressing xopH. Error bars indicate s.e.m. $\mathbf{b}$ Digestion and HPLC

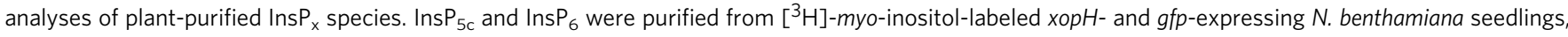
respectively (see "Methods" section). XopH-treated or non-treated Ins $\mathrm{P}_{\mathrm{x}}$ species (as designated) were then separated by SAX-HPLC. XopH was inactivated by incubating the reaction mixture at $95^{\circ} \mathrm{C}$ for $15 \mathrm{~min}$. $\mathbf{c} \mathrm{XopH}_{\mathrm{H}}$ hydrolyzes $\operatorname{lns} \mathrm{P}_{6}$ to $\operatorname{lns} \mathrm{P}_{5}$ during $\mathrm{Xcv}_{\mathrm{c}}$ infection. $\mathrm{TiO}_{2}$ bead enrichment of inositol polyphosphates from $N$. benthamiana leaf extracts infected with Xcv 85-10 $\Delta x o p Q(W T), 85-10 \Delta x o p Q \_f s-x o p H$ (fs-xopH), and the complemented mutant, where $x o p H$ was re-integrated into the genome (see "Methods" section). Inositol polyphosphates were eluted from $\mathrm{TiO}_{2}$ beads, resolved by PAGE and visualized by toluidine blue staining. Protein extracts were visualized by Coomassie blue as a loading control. The experiments were repeated twice (a, $\mathbf{c}$ ) or once (b) with similar results 
a
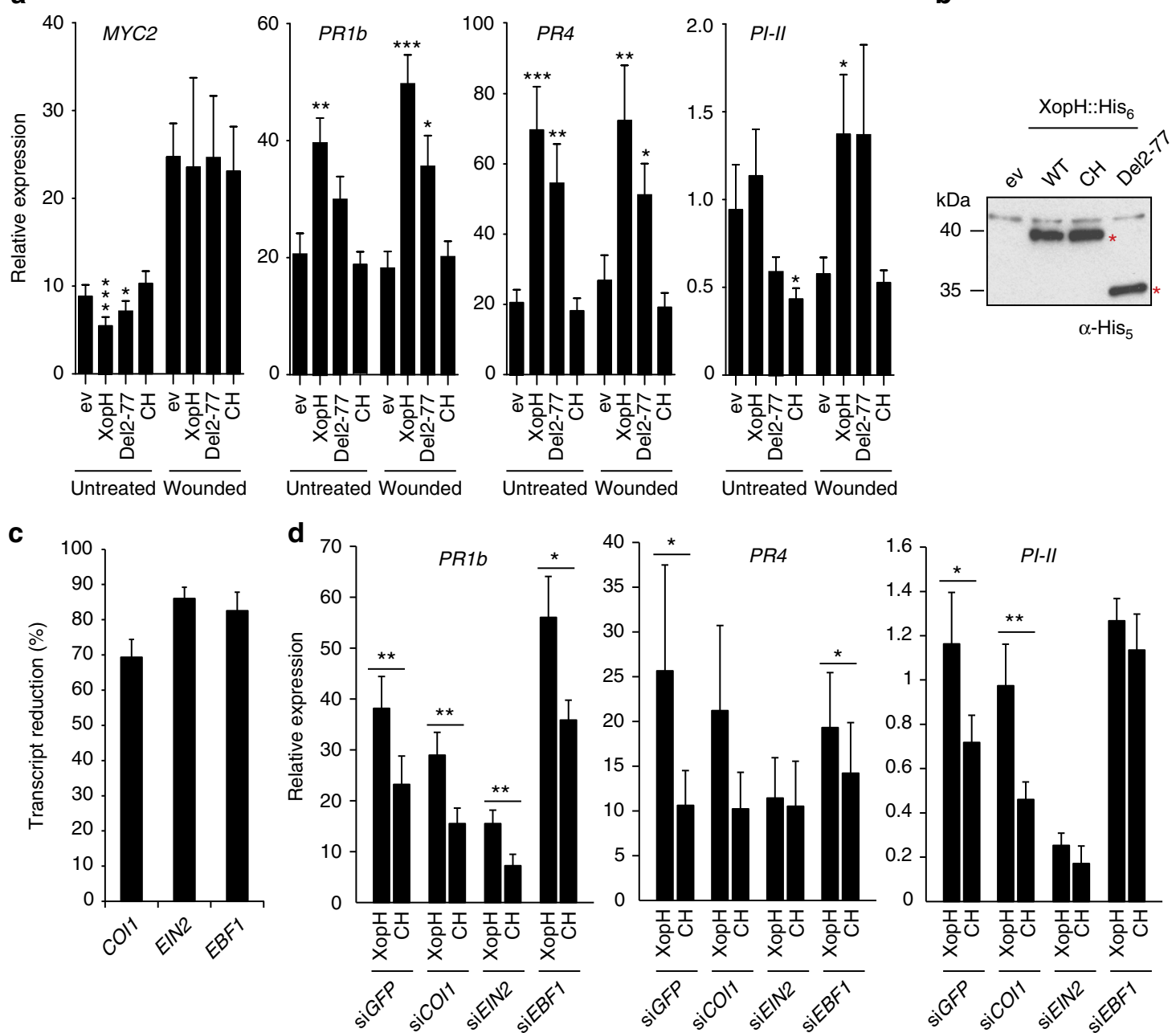

Fig. $8 \mathrm{XopH}$ phytase activity affects plant hormone pathways. a qRT-PCR analysis of $\mathrm{N}$. benthamiana leaves transiently expressing XopH and mutant derivatives, untreated or 20 min post wounding. ev empty T-DNA. Asterisks indicate statistically significant differences to corresponding ev samples (Mann-Whitney test; ${ }^{\star} p<0,05 ;{ }^{\star \star} p<0,01 ;{ }^{\star \star *} p<0,001$ ). b Protein expression two dpi in the same plants analyzed in a. Immunoblot signals at expected sizes are marked by asterisks. c QRT-PCR analysis of COI1-, EIN2-, and EBF1-silenced N. benthamiana plants (siCOI1, siEIN2, and siEBF1) transiently expressing $\mathrm{XopH}$ and its catalytically inactive variant $(\mathrm{CH})$, respectively. GFP-silenced plants (siGFP) served as control. Asterisks indicate statistically significant differences (Student's $t$ test; ${ }^{\star} p<0,05 ;{ }^{\star \star} p<0,01$ ). d Silencing efficiencies determined by qRT-PCR. Values indicate percent reduction of COI1, EIN2, and EBF1 transcript levels in the respective silenced plants, relative to GFP-silenced plants, both expressing inactive $\mathrm{XopH}_{\mathrm{CH}}$. Combined data from three independent experiments (with three biological replicates per experiment) are shown (a, c, d). Error bars indicate s.e.m.

Construction of xopH mutants in $\mathbf{X c v}$. The $x o p H$ frameshift mutant (fs- $x \circ p H$ ) carries a 4-bp insertion after nucleotide (nt) position 53 of the $x o p H$ ORF generating a $P f o I$ restriction site and resulting in an early stop codon at nt position 76. For this, plasmid pOK-early-stop-xopH was used containing two $\sim 670$-bp PCR fragments from chromosomal DNA of $X c v$ strain 85-10, which were combined in pUC57 prior to PCR-based transfer into suicide vector pOK $1^{45}$. Positive $X c v 85$ 10 fs- $x \circ \mathrm{pH}$ colonies were identified by $P f o I$ digestion and sequencing of PCR amplicons. To generate a $\Delta x o p Q \_f s-x o p H$ double mutant, suicide plasmid pOGG2: xopQ was used ${ }^{26}$.

XopH derivatives and controls. Generally, DNA fragments were amplified using Hybrid DNA Polymerase (Roboklon, Berlin, Germany) unless stated otherwise. All cloned fragments were sequenced. Oligonucleotides are listed in Supplementary Table 1. Constructs were generated by GATEWAY ${ }^{46}$ and In-Fusion HD (Takara Bio USA, Inc., Mountain View, USA) cloning technology according to the manufacturer's protocols.

To generate expression constructs for $\mathrm{XopH}_{-\mathrm{His}_{6}}$ and XopH-Del2-77-His ${ }_{6}$, PCR-amplified $x \circ \mathrm{pH}$ fragments were cloned into pENTR/D-TOPO (Thermo Fisher Scientific, Darmstadt, Germany). To generate pENTR/D:xopH-C267A-his ${ }_{6}$, the Phusion Site-Directed Mutagenesis Kit (Thermo Fisher Scientific) was used according to the manufacturer's protocol. pENTR/D:xopH-H239A-his ${ }_{6}$, pENTR/D: xopH-mutP48-52-53-his ${ }_{6}$ (PRR1 mutant), pENTR/D:xopH-mutP69-71-his 6
(PRR2-1 mutant), and pENTR/D:xopH-mutP73-74-75-76-his 6 (PRR2-2 mutant) were derived from pENTR/D:xopH-his ${ }_{6}$ using the QuikChange Lightning SiteDirected Mutagenesis Kit (Agilent Technologies). To generate pENTR/D:xopHC267A-H239A-his 6 (CH), pENTR/D:xopH-C267A-his ${ }_{6}$ served as template for sitedirected mutagenesis. Entry clones were transferred into the GATEWAYcompatible expression vectors pAG416-GAL-ccdB-HA for yeast (gift from Susan Lindquist; Addgene plasmid \#14243) and pGWB2 for plants ${ }^{47}$.

For localization studies, constructs for expression of GFP-XopH-His fusions $_{6}$ with nuclear import (NLS), export (NES), or mutated export (nes) signal were generated by SOE (splicing by overlap extension) PCR using Q5 High Fidelity Polymerase (New England BioLabs, Frankfurt/Main, Germany), cloned into pENTR/D-TOPO and transferred into pGWB2. As control, PCR-amplified $g f p$ was cloned into pENTR/D-TOPO and transferred into pGWB $408^{48}$.

For expression in E. coli, PCR-amplified xopH-his ${ }_{6}$ and $x o p H-d e l 2-77-h i s_{6}$ fragments were cloned into NdeI/XhoI-digested pET22b(+) vector (Merck Millipore, Darmstadt, Germany) using In-Fusion HD cloning.

For complementation, $x \circ \mathrm{pH}, x_{\mathrm{opH}} \mathrm{CH}_{\mathrm{CH}}$, and $\mathrm{xopH}_{\mathrm{Del2}-77}$, respectively, under control of the native $x o p H$ promoter $(344 \mathrm{bp})$ and followed by the avrBs 1 terminator region (208 bp) was inserted into a defined site into the genome of fs$x o p H$ mutants using derivatives of the suicide vector pLAND- ${ }^{49}$. To allow translocation of $\mathrm{XopH}_{\text {Del2-77 }}$ by the $X c v$ T3S system, a 231-bp fragment encoding the sequence-unrelated T3S signal of AvrBs3 (aa 2-78) was cloned in front of $x o p H_{D e l 2-77}$. Cloning details are available upon request. 
Generation of transgenic $\mathbf{x o p H}$ plants. N. benthamiana was transformed using Agrobacterium GV3101 containing pGWB2:xopH-his $s_{6}$ and pGWB2:xopH-H239A-

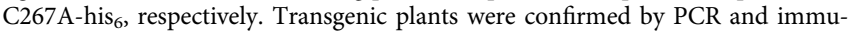
noblot. Here, T2 plants were used.

Virus-induced gene silencing. For silencing of COI1, EIN2, and EBF1, 190-, 434-, and 251-bp fragments, respectively, were PCR-amplified from N. benthamiana cDNA and cloned into pENTR/D-TOPO (ThermoFisher Scientific). Oligonucleotides are listed in Supplementary Table 1. The fragments were recombined into the GATEWAY-compatible tobacco rattle virus (TRV) RNA2 vector pYL279A $\mathrm{A}^{50}$. VIGS was initiated by Agrobacterium-mediated co-delivery of pYL279A derivatives and pTRV-RNA ${ }^{51}$

Immunoblot analysis. Plant samples were prepared and analyzed as described ${ }^{52}$ using an $\alpha-\mathrm{His}_{5}$ antibody (Qiagen, Hilden, Germany; Cat No./ID: 34660; diluted 1:2000). Unprocessed blot images are shown in Supplementary Fig. 12.

qRT-PCR analysis. Five $N$. benthamiana plants were inoculated with $A$. tumefaciens GV3101 containing pGWB2:xopH-his ${ }_{6}$, pGWB2:xopH-del2-77-his ${ }_{6}$, pGWB2: xopH-H239A-C267A-his ${ }_{6}$, or empty pGWB2. For better protein expression, the strains were mixed 1:1 with GV3101 mediating expression of silencing inhibitor $\mathrm{p} 19^{53}$. Three dpi, two leaf discs per plant ( $\varnothing$ nine $\mathrm{mm}$ ), i.e., five biological replicates, were harvested before and $20 \mathrm{~min}$ after wounding of the leaf with forceps.

Silencing plants were analyzed 14-15 days after VIGS initiation. Nine plants per silencing construct were inoculated with GV3101 containing pGWB2:xopH-his 6 and pGWB2:xopH-H239A-C267A-his ${ }_{6}$, respectively, and two leaf discs per plan were harvested. Three plants were pooled per biological replicate.

Total RNA was isolated from leaf samples using standard Trizol reagent ${ }^{54}$. An aliquot of $5 \mu \mathrm{g}$ of total RNA was reverse-transcribed using RevertAid Reverse Transcriptase (Thermo Fisher Scientific). qPCR analyses were performed on an Mx3005P qPCR System (Agilent Technologies) using the Maxima SYBR Green/ ROX qPCR Master Mix (Thermo Fisher Scientific) and oligonucleotides listed in Supplementary Table 1. Data are shown relative to the house-keeping genes F-Box and $L R 23$.

To ensure adequate statistical power, qPCR data of three independent experiments were combined and statistically analyzed (two-group comparisons; $n \geq 9$ ). For ХopH overexpression experiments (Fig. 8a), the two-tailed Mann-Whitney test (non-parametric) was used. For VIGS experiments (Fig. 8d), one-tailed paired $t$ tests were performed $\left(\mathrm{XopH}_{\mathrm{CH}}\right.$ served as reference, assuming induction of transcript accumulation by WT XopH).

Protein expression in E. coli and purification. Freshly transformed E. coli BL21 (DE3) cells carrying recombinant pET22b(+) and pSKE6, respectively, were cultivated overnight in LB broth containing $50 \mu \mathrm{g} \mathrm{mL}^{-1}$ ampicillin or kanamycin and $0.5 \%$ glucose $\left(37^{\circ} \mathrm{C}, 160 \mathrm{rpm}\right)$. For expression, LB broth containing $100 \mu \mathrm{g} \mathrm{m} \mathrm{L}^{-1}$ ampicillin or $50 \mu \mathrm{g} \mathrm{mL}^{-1}$ kanamycin was inoculated at $\mathrm{OD}_{600}=0.05$ with overnight culture and incubated $\left(37^{\circ} \mathrm{C}, 160 \mathrm{rpm}\right)$. At $\mathrm{OD}_{600}=0.8$, protein expression was induced by $1 \mathrm{mM}$ IPTG and 3\% ethanol (final concentration). After $5 \mathrm{~h}$, cells were harvested by centrifugation at $5000 \mathrm{rpm}$ (Beckman JA-10 fixed-angle rotor) for 10 min at $4{ }^{\circ} \mathrm{C}$. Cell pellets were stored at $-20^{\circ} \mathrm{C}$ until protein preparation.

For XopH protein preparation, cell pellets were resuspended in $100 \mathrm{mM}$ HEPES $\mathrm{pH} 7.5,300 \mathrm{mM} \mathrm{NaCl}, 0.5 \%$ glycerol, $10 \mathrm{mM}$ imidazole containing $1 \mathrm{mg} \mathrm{mL}^{-1}$ lysozyme, and EDTA-free protease inhibitor cocktail (Roche, Sigma-Aldrich,

Munich, Germany). After $30 \mathrm{~min}$ on ice, cells were disrupted by three freeze-thaw cycles $\left(30^{\circ} \mathrm{C}\right.$ water bath, liquid nitrogen). After $30 \mathrm{~min}$ incubation on ice with 50 $\mu \mathrm{g} \mathrm{m}^{-1}$ DNase $1 / \mathrm{RNase}$ A, cell lysate was collected by centrifugation $(20,000 \times g$, $30 \mathrm{~min}, 4^{\circ} \mathrm{C}$ ). Proteins were purified using HisLink ${ }^{\mathrm{TM}}$ Protein Purification Resin (Promega, Mannheim, Germany) according to the manufacturer's protocol. Wash buffer: $100 \mathrm{mM}$ HEPES pH 7.5, $300 \mathrm{mM} \mathrm{NaCl}, 0.5 \%$ glycerol, $10 \mathrm{mM}$ imidazole; elution buffer: $100 \mathrm{mM}$ HEPES pH 7.5, $300 \mathrm{mM} \mathrm{NaCl}, 0.5 \%$ glycerol, and $500 \mathrm{mM}$ imidazole. Protein concentration was determined using the molar extinction coefficient ${ }^{55}$. Protein purity $(>90 \%)$ was checked by SDS-PAGE and Coomassie staining.

The construct pMCSG57-hopAO1 for the synthesis of full-length HopAO1, Nterminally fused to $6 \mathrm{xHis}$, was obtained from the DNASU plasmid repository (https://dnasu.org/DNASU/Home.do). $\mathrm{His}_{6}::$ HopAO1 was expressed in E. coli BL21-CodonPlus (DE3)-RIL cells (Stratagene, San Diego, USA) and purified similar to the yeast Sfh1 protein ${ }^{56}$. Prior to activity assays, the purified protein was dialyzed in buffer containing $300 \mathrm{mM} \mathrm{NaCl}, 25 \mathrm{mM} \mathrm{Na}_{2} \mathrm{HPO}_{4}(\mathrm{pH} 7.5)$, and $5 \mathrm{mM}$ $\beta$-mercaptoethanol.

General phosphatase activity. Phosphatase activity using $0.25 \mu \mathrm{g} \mu \mathrm{L}^{-1}$ protein and $20 \mathrm{mM} \mathrm{pNPP}$ as a substrate was analyzed at $37^{\circ} \mathrm{C}$ with the JBS Phosphatase Assay Kit (Jena Bioscience, Jena, Germany) according to the manufacturer's protocol. Reaction buffer contained $100 \mathrm{mM} \mathrm{NaCl}, 1 \mathrm{mM} \mathrm{MgCl}_{2}, 5 \%$ glycerol, $0.1 \%$ ßmercaptoethanol in $50 \mathrm{mM}$ MES, HEPES, or sodium acetate, and different $\mathrm{pH}$. Extinction at $405 \mathrm{~nm}$ was recorded using a Spectrostar Nano microplate reader (BMG Labtech, Ortenberg, Germany). The experiment was done twice with similar results, using two independent protein preparations each.
Phosphopeptide microarray. The 13-mer peptide microarray used for profiling the XopH-phosphatase activity consists of 6207 peptides, each containing one phospho-tyrosine residue in the central position ${ }^{57-59}$. Each phosphopeptide is displayed in triplicates on the glass surface enabling quality control and intra-chip reproducibility. Peptides were synthesized by SPOT synthesis technology on cellulose membranes according to R. Frank ${ }^{60}$. After deprotection of side chains by 95\% trifluoroacetic acid, spots were punched out into wells of 96 -microtiter plates. Phosphopeptides were released from the cellulose membrane by treatment with $5 \%$ aqueous triethylamine. After separation of the peptide solution from the cellulose disks and evaporation of the cleavage solution peptide derivatives were redissolved in printing buffer and transferred into 384-well plates. Peptides were printed onto epoxy-functionalized glass slides using an OmniGrid300 contact printer. Finally, microarray surfaces were passivated at $40^{\circ} \mathrm{C}$ using bovine serum albumin in citrate buffer.

Peptide microarrays reacted with XopH or the C267A variant yielded 82 and 238 substrate peptides, respectively, showing more than $70 \%$ signal decrease as compared to the control experiment without enzyme. Two types of control experiments were performed to distinguish between signal decrease caused by enzymatic action and signal decrease because of enzyme bound to the immobilized phosphopeptides and masking the epitope for the phospho-specific antibody (P100; Cell Signaling Technologies, Leiden, the Netherlands). First, peptide microarrays were treated with $\alpha$-XopH-antibody (BioGenes, Berlin, Germany; polyclonal $\alpha$-peptide antibody against aa $43-56$ : ELADLPSRQPPRSK) to check if mutant binds to phosphopeptides (trapping mutant). Additional washing steps with $6 \mathrm{M}$ urea were performed to denature bound enzyme molecules. Second, the peptide microarrays were treated with enzyme in presence of inhibitor $(100 \mu \mathrm{M}$ sodium orthovanadate), or in the presence of competing substrate (pTyr2). All control experiments showed that XopH and the C267A variant did not bind to immobilized phosphopeptides under the conditions used. Thus, any epitopemasking effect can be excluded.

Protein phosphatase assay on peptide microarrays. $\mathrm{XopH}$ and $\mathrm{XopH}_{\mathrm{C} 267 \mathrm{~A}}$ were incubated at room temperature (RT) with the peptide microarray using the TECAN Hybstation HS400. Prior to phosphatase treatment, two wash steps with phosphate-buffered saline ( $\mathrm{pH} 7.5$ ) with $0.1 \%$ Tween 20 (PBST) and one wash step with PBS buffer were applied. Microarray blocking was performed with PBST and $3 \%$ bovine serum albumin (BSA) for $10 \mathrm{~min}$, followed by $2 \times$ PBST and $1 \times$ PBS wash steps. Peptide microarrays were treated for $2 \mathrm{~h}$ with $10 \mu \mathrm{g} \mathrm{mL}^{-1}$ enzyme in reaction buffer (50 mM HEPES, pH 7.0, $100 \mathrm{mM} \mathrm{NaCl}, 1 \mathrm{mM}$ dithiothreitol (DTT) $1 \mathrm{mM} \mathrm{MgCl} 2$ and 3\% BSA). A control experiment without enzyme was done to obtain starting signal intensities for each spot. After washing with $5 \times$ PBST and $1 \times$ PBS buffer $\alpha$-phospho-tyrosine mouse antibody (Cell Signaling Technology Europe, Leiden, the Netherlands) was applied at $10 \mu \mathrm{gL}^{-1}$ concentration in PBST + $3 \%$ BSA for $1 \mathrm{~h}$ followed by $5 \times$ PBST and $1 \times$ PBS wash steps. For staining the phosphopeptide-bound antibody Dylight649-labeled anti-mouse IgG (Pierce, Thermo Fisher Scientific) was used (30 min at $1 \mu \mathrm{g} \mathrm{mL}^{-1}$ in PBST, 3\% BSA). Final washing steps were carried out with $5 \times$ PBST, $1 \times$ PBS, $2 \times$ distilled $\mathrm{H}_{2} \mathrm{O}$ and $2 \times$ nitrogen drying. To check for XopH binding to immobilized phosphopeptides, we applied $\alpha$-XopH-antibody (1:5000 diluted, $1 \mathrm{~h}$ ), followed by $5 \times$ PBST, $1 \times$ PBS washing steps and Alexa Fluor 532-labeled $\alpha$-rabbit IgG (Thermo Fisher Scientific) at $1 \mu \mathrm{g} \mathrm{mL}^{-1}$ concentration for $30 \mathrm{~min}$ followed by $5 \times$ PBST, $1 \times \mathrm{PBS}, 2 \times \mathrm{dH}_{2} \mathrm{O}$ and $2 \times$ nitrogen drying. To determine if the signal decrease is caused by enzymatic action, we performed control experiments with inhibited phosphatase $(0.1 \mathrm{mM}$ sodium orthovanadate (Sigma-Aldrich)) or in the presence of excess of competing substrate $(600 \mu \mathrm{M}$ pTyr2-peptide (DADE(pY)LIPQQG) using similar conditions for the microarray experiments. To remove bound phosphatase molecules from the immobilized phosphopeptides, we added two urea wash steps $(20 \mathrm{~min}$ each) after XopH incubation $\left(1 \times 6 \mathrm{M}\right.$ urea and $1 \times 3 \mathrm{M}$ urea in $\mathrm{dH}_{2} \mathrm{O}, \mathrm{pH}$ 7.4) followed by $3 \times$ $\mathrm{dH}_{2} \mathrm{O}$ wash steps. Fluorescence imaging of peptide microarrays was done using an Axon GenePix 4000B scanner at appropriate wavelengths, resolution $10 \mu \mathrm{m}$ per pixel. Image evaluation was performed with GenePix Pro 7.2 (www. moleculardevices.com) followed by statistical analyses to identify top substrates and create two-sample logos ( $t$ test was chosen as statistical test and amino acid residue was shown if $p$ value was below 0.05 ; http://www.twosamplelogo.org/cgi-bin/tsl/tsl. cgi).

High-performance liquid chromatography kinetics. Phosphorylated peptides (pTyr2: Ac-DADE-pY-LIPQQGW-NH ${ }_{2}$, pTyr-chip: Ac-KVDVDE-pYDENKFVW- $\mathrm{NH}_{2}$ and negative control Ac-GRKKIK-pY-KSLTRNW-NH ${ }_{2}$ ) were purchased from JPT Peptide Technologies (Berlin, Germany). Phosphopeptides were dissolved in $50 \mathrm{mM}$ HEPES, pH 7.0, $10 \mathrm{mM} \mathrm{NaCl}, 1 \mathrm{mM} \mathrm{DTT}, 1 \mathrm{mM} \mathrm{MgCl}$ at $0.5-50 \mu \mathrm{M}$ at $37^{\circ} \mathrm{C}$ and reaction was started by addition of $0.05 \mathrm{mg} \mathrm{mL}^{-1} \mathrm{XopH}$. Reactions were stopped at different time points (1-120 min) by addition of $10 \%(\mathrm{v} /$ v) trifluoroacetic acid (TFA) to a final concentration of $1 \%$ TFA (v/v). Reactions were analyzed using an Agilent 1100 series HPLC and Kinetex 2.6 $\mu \mathrm{m}$ XB-C18 100 A, $50 \times 3.0 \mathrm{~mm}$ column for separation. Peak areas of phosphorylated and dephosphorylated peptides at different time points were used to determine the velocity of enzymatic reaction. Nonlinear regression according to Michaelis-Menten model and calculation of $K_{\mathrm{M}}$ and $k_{\text {cat }}$ was performed using GraphPad Prism 5.01 software (www.graphpad.com). 
Chemical synthesis and analysis of pure InsP $_{6} .{ }^{1} \mathrm{H}$-NMR spectra were recorded on a Bruker $400 \mathrm{MHz}$ spectrometer at $298 \mathrm{~K}$ in the indicated deuterated solvent. Data are reported as follows: chemical shift $(\delta, \mathrm{ppm})$, multiplicity (s, singulet; $\mathrm{d}$, doublet; $\mathrm{t}$, triplet; q, quartet; $\mathrm{m}$, multiplet, or not resolved signal; br, broad signal), coupling constant(s) (J, Hz), integration. All signals were referenced to the internal solvent signal as standard $\left(\mathrm{CDCl}_{3}, \delta\right.$ 7.26; $\mathrm{D}_{2} \mathrm{O}, \delta$ 4.79; $\mathrm{CD}_{3} \mathrm{OD}, \delta$ 3.31; DMSO-d6, $\delta$ 2.50). ${ }^{31} \mathrm{P}\left[{ }^{1} \mathrm{H}\right]$-NMR spectra and ${ }^{31} \mathrm{P}$-NMR spectra were recorded with ${ }^{1} \mathrm{H}$ decoupling or ${ }^{1} \mathrm{H}$ coupling on Bruker $162 \mathrm{MHz}$ or $202 \mathrm{MHz}$ spectrometers at $298 \mathrm{~K}$ in the indicated deuterated solvent. All signals were referenced to an internal standard (PPP). ${ }^{13} \mathrm{C}\left[{ }^{1} \mathrm{H}\right]$-NMR spectra were recorded with ${ }^{1} \mathrm{H}$-decoupling on Bruker 101 or $125 \mathrm{MHz}$ spectrometers at $298 \mathrm{~K}$ in the indicated deuterated solvent. All signals were referenced to the internal solvent signal as standard $\left(\mathrm{CDCl}_{3}, \delta 77.0\right.$; $\mathrm{CD}_{3} \mathrm{OD}, \delta 49.0$; DMSO-d6, $\delta$ 39.5). Mass spectra were recorded on Finnigan MAT95 MS, Bruker Esquire LC MS, Bruker maXis QToF HRMS and Finnigan TSQ700 MS machines. The chemical synthesis is outlined in Supplementary Fig. 5a, analytical data in Supplementary Fig. 5b-d. Synthesis was carried out as follows:

Synthesis of protected hexakisphosphate 2: $50.0 \mathrm{mg}(0.277 \mathrm{mmol}, 1.00 \mathrm{eq}$.) of myo-inositol (1) and $2.27 \mathrm{~g}$ (4.49 mmol, 16.0 eq.) of 9-fluorenylmethyl phosphoramidite (Fm-PA) were coevaporated with dry MeCN $(3 \mathrm{~mL})$. The residue was dissolved in dry DMF ( $5 \mathrm{~mL}$ ). To this solution, $654 \mathrm{mg}(5.54 \mathrm{mmol}, 20.0$ eq.) of 4,5-dicyanoimidazole were added. Progress of the reaction was monitored by ${ }^{31} \mathrm{P}$ NMR. After completion of the reaction (30-45 min), oxidation was achieved by slow addition of $763 \mathrm{mg}$ ( $4.49 \mathrm{mmol}, 16.0$ eq.) $\mathrm{mCPBA}$ (70\%, moistened with water) at $0{ }^{\circ} \mathrm{C}$. The mixture was concentrated in vacuo and the product was crystalized from $\mathrm{MeOH}(5 \mathrm{~mL})$ and purified by flash chromatography $\left(\mathrm{CH}_{2} \mathrm{Cl}_{2}\right.$ : $\mathrm{MeOH}$; 10:0.1 to 10:1) yielding $245 \mathrm{mg}$ of 2 as a white solid (0.088 mmol, $32 \%$ ). TLC $\left(\mathrm{CH}_{2} \mathrm{Cl}_{2}: \mathrm{MeOH} ; 10: 0.1 \mathrm{v} / \mathrm{v}\right): R_{\mathrm{f}}=0.50 ;{ }^{1} \mathrm{H}-\mathrm{NMR}\left(400 \mathrm{MHz}, \mathrm{CDCl}_{3}\right): \delta$ 7.78-7.52 (m, 30 H), 7.52-7.39 (m, 14 H), 7.39-7.00 (m, 52 H), 4.76-4.19 (m, 28 $\mathrm{H}), 4.17-3.81(\mathrm{~m}, 14 \mathrm{H}) ;{ }^{13} \mathrm{C}-\mathrm{NMR}\left(126 \mathrm{MHz}, \mathrm{CDCl}_{3}\right): \delta 143.45-142.89(\mathrm{~m})$, $141.50-141.21(\mathrm{~m}), 127.80-126.92(\mathrm{~m}), 125.83-125.23(\mathrm{~m}), 120.01-119.76(\mathrm{~m})$, $77.55,77.24,76.92,74.83,73.50,70.07,69.99,69.53,60.47,47.94,47.78,21.14$, $14.33 ;{ }^{31} \mathrm{P}\left\{{ }^{1} \mathrm{H}\right\}$-NMR $\left(162 \mathrm{MHz}, \mathrm{CDCl}_{3}\right) \delta 1.09(\mathrm{~s}), 0.35(\mathrm{~s}),-0.02(\mathrm{~s}),-1.69(\mathrm{~s}) ;$ ${ }^{31} \mathrm{P}-\mathrm{NMR}\left(162 \mathrm{MHz}, \mathrm{CDCl}_{3}\right): \delta 1.37-0.81(\mathrm{~m}), 0.53-0.15(\mathrm{~m}), 0.14--0.17(\mathrm{~m})$, $-1.40--2.02(\mathrm{~m})$; HRMS (ESI) $[\mathrm{M}+2 \mathrm{Na}]^{2+}$ calcd for $\mathrm{C}_{174} \mathrm{H}_{138} \mathrm{Na}_{2} \mathrm{O}_{24} \mathrm{P}_{6}$, 1421.8911; found, 1421.8933 .

Synthesis of Ins $_{6}: 40.0 \mathrm{mg}$ ( $14.3 \mu \mathrm{mol}, 1.00$ eq.) of 2 were dissolved in DMF (3 $\mathrm{mL}$ ) and piperidine $(0.5 \mathrm{~mL})$ was added. The solution was stirred for $1 \mathrm{~h}$ at RT. After completion of the deprotection, the solution was concentrated and the product was precipitated with $10 \mathrm{~mL} \mathrm{Et}_{2} \mathrm{O}$. The precipitate was isolated by centrifugation, dissolved in $\mathrm{MeOH}$, and crystallized by addition of $\mathrm{Et}_{2} \mathrm{O}$. Centrifugation was repeated and crystals were dried in vacuo. Piperidinium counter ions were exchanged to sodium ions by addition of excess $\mathrm{NaI}$ to a $\mathrm{MeOH}$ solution of the piperidinium salt of $\mathbf{3}$. After $30 \mathrm{~min}$ of stirring, the pure sodium salt of 3 precipitated, evidenced by the absence of proton resonances of piperidinium ions in the ${ }^{1} \mathrm{H}$-NMR spectrum. The purity was confirmed by ion chromatography as described in the next section. Yield: $12.2 \mathrm{mg}$ of 3 (13.2 $\mu \mathrm{mol}, 92 \%) .{ }^{1} \mathrm{H}-\mathrm{NMR}$ $\left(400 \mathrm{MHz}, \mathrm{D}_{2} \mathrm{O}\right): 4.86(\mathrm{dd}, J=10.1 \mathrm{~Hz}, J=10.1 \mathrm{~Hz}, 1 \mathrm{H}), 4.44(\mathrm{ddd}, J=9.5 \mathrm{~Hz}, J=$ $9.5 \mathrm{~Hz}, J=9.5 \mathrm{~Hz}, 2 \mathrm{H}), 4.25-4.13(\mathrm{~m}, 3 \mathrm{H}) ;{ }^{13} \mathrm{C}-\mathrm{NMR}\left(101 \mathrm{MHz}, \mathrm{D}_{2} \mathrm{O}\right): \delta 77.44$, 75.99, 75.38, 73.26; ${ }^{31} \mathrm{P}\left\{{ }^{1} \mathrm{H}\right\}-\mathrm{NMR}\left(162 \mathrm{MHz}, \mathrm{D}_{2} \mathrm{O}\right): \delta 2.34(\mathrm{~s}), 1.87(\mathrm{~s}), 1.36(\mathrm{~s})$, $0.89(\mathrm{~s}) ;{ }^{31} \mathrm{P}-\mathrm{NMR}\left(162 \mathrm{MHz}, \mathrm{D}_{2} \mathrm{O}\right): \delta 2.34(\mathrm{~d}, J=9.6 \mathrm{~Hz}), 1.87(\mathrm{~d}, J=9.5 \mathrm{~Hz}), 1.36$ $(\mathrm{d}, J=9.2 \mathrm{~Hz}), 0.89(\mathrm{~d}, J=9.8 \mathrm{~Hz})$; HRMS (ESI) $\left[\mathrm{M}-12 \mathrm{Na}^{+}+10 \mathrm{H}^{+}\right]^{2-}$ calculated for $\mathrm{C}_{6} \mathrm{H}_{16} \mathrm{O}_{24} \mathrm{P}_{6}, 328.9234$; measured, 328.9234 .

Phytase assay. Ins $\mathrm{P}_{6}$ was purchased from Sichem (Bremen, Germany) or synthesized as outlined above. For initial experiments, also Ins $\mathrm{P}_{6}$ from Sigma-Aldrich was used. Ins $\mathrm{P}_{5}$ isomers were from Sichem. Reaction mixtures $(50 \mu \mathrm{L})$ of $0.05 \mu \mathrm{g} \mu \mathrm{L}$ ${\mathrm{XopH}:: \mathrm{His}_{6}, 0.01 \mathrm{mM} \mathrm{InsP}}_{6}, 50 \mathrm{mM}$ HEPES (pH 7.0), 5\% glycerol and $0.1 \%$ ßmercaptoethanol were prepared in 96-well plates. Salt concentration varied from 10 to $1000 \mathrm{mM} \mathrm{NaCl}$. The concentration of tested metal ions $\left(\mathrm{MgCl}_{2}, \mathrm{CaCl}_{2}, \mathrm{MnCl}_{2}\right.$, $\mathrm{ZnCl}_{2}$, and $\mathrm{KCl}$ ) and EDTA was $1 \mathrm{mM}$. For $\mathrm{pH}$ profiling, the Wizard $\mathrm{pH}$ buffer screen from Rigaku (Bainbridge Island, USA) was used. The concentration of the alternative phytase substrates glucose 6-phosphate, glycerophosphate, and fructose 1,6-bisphosphate (Sigma-Aldrich) was $10 \mu \mathrm{M}$. The enzymatic reaction was started by adding substrate and stopped after $1 \mathrm{~h}$ incubation at $37^{\circ} \mathrm{C}$ by adding $50 \mu \mathrm{L}$ Molybdate Dye/Additive mixture (Promega). After $5 \mathrm{~min}$, the reaction was analyzed at $620 \mathrm{~nm}$ in a Spectrostar Nano microplate reader (BMG Labtech). Phosphate standard was prepared according to the manufacturer's protocol (Promega, Wisconsin, USA). The extinction was corrected for substrate in buffer. Protein phosphatase activity is reported as release of inorganic phosphate $\left(\mathrm{P}_{\mathrm{i}}\right)$ per minute per $\mu$ g protein. All experiments were done at least twice with similar results, using two independent protein preparations each. The enzyme kinetics were analyzed in the range of $0-60 \mu \mathrm{M} \mathrm{InsP_{6 }}$. Data were fitted to Michaelis-Menten equation using KaleidaGraph4.0.

PAGE and purification of the XopH product from the gel. For PAGE, $10 \mathrm{nmol}$ Ins $\mathrm{P}_{6}$ were incubated with $0.13 \mu \mathrm{g} \mu \mathrm{L}^{-1} \mathrm{XopH}$ for $1 \mathrm{~h}$ at $28^{\circ} \mathrm{C}$ in $15 \mu \mathrm{L}$ reaction buffer composed of $50 \mathrm{mM}$ HEPES ( $\mathrm{pH} 7.0$ ), $10 \mathrm{mM} \mathrm{NaCl}, 5 \%$ glycerol, and $0.1 \%$ B-mercaptoethanol. XopH reaction products were separated using PAGE and purified by two dehydration-hydration cycles ${ }^{61}$. Unprocessed gel images are provided in Supplementary Fig. 13.

MALDI MS. XopH $\left(0.13 \mu \mathrm{g} \mu \mathrm{L}^{-1}\right)$ digests of $\operatorname{InsP}_{6}(100 \mathrm{nmol})$ in $150 \mu \mathrm{L}$ buffer (50 $\mathrm{mM}$ HEPES (pH 7.0), $10 \mathrm{mM} \mathrm{NaCl}, 5 \%$ glycerol and $0.1 \%$ ß-mercaptoethanol) for $1 \mathrm{~h}$ at $28^{\circ} \mathrm{C}$ were purified by PAGE as described above. XopH reaction products were then analyzed by MALDI-ToF-MS (9-aminoacridine matrix) ${ }^{61}$.

NMR spectroscopy. Spectra were recorded on a Bruker Avance III HD 600 equipped with a BOSS-3 shim system, a digital lock control unit, a BCU II cooling unit, a GAB gradient spectroscopy and $5 \mathrm{~mm} \mathrm{BB}$ observe probe $(1 \mathrm{H}$; 19F-109Ag; $564.7-27.9 \mathrm{MHz}$ ). The samples were held at $300 \mathrm{~K}$ during the measurements (NS: 8-16k, AQ: 0.34 s, DW: 5.2 us, D1: $2 \mathrm{~s}$ )

$\mathrm{Ins}_{5}[1-\mathrm{OH}]$ and $\mathrm{Ins}_{5}[3-\mathrm{OH}]$ as decasodium salts $(1 \mathrm{mg}$ batches, dissolved as a stock solution in $100 \mu \mathrm{L} \mathrm{D} \mathrm{D}_{2} \mathrm{O}$ ) were from Sichem. Enantiopure L-arginine amide dihydrochloride (L-Arg-N) was purchased from Sigma-Aldrich.

XopH $\left(0.13 \mu \mathrm{g} \mathrm{LL}^{-1}\right)$ digests of InsP $\mathrm{P}_{6}(600 \mathrm{nmol})$ in buffer $(150 \mathrm{mM}$ ammonium acetate, $\mathrm{pH}$ 7.1) were concentrated to a volume of ca. $300 \mu \mathrm{L}$ and then diluted with $\mathrm{D}_{2} \mathrm{O}$ to enable locking (total volume $600 \mu \mathrm{L}$ ). Residual XopH activity was destroyed by heating to $95^{\circ} \mathrm{C}$ for $15 \mathrm{~min}$. Spiking of the sample was performed with commercial InsP $\mathrm{P}_{5}$ in different ratios (1.5:1, 1:1, and 1:1.5) in the presence of L-Arg$\mathrm{N}$ (100- to 150-fold excess, adjusted during the spiking experiments).

HPIC analysis. For high-performance ion chromatography (HPIC), two different devices were used. For the data presented in Fig. 4c, a Thermo Scientific Dionex ICS- $5000^{+}$chromatograph using a dual pump equipped with a $10 \mu \mathrm{L}$ injector loop, a Dionex CarboPac PA100 guard column $(4 \times 50 \mathrm{~mm})$ and Dionex CarboPac PA100 analytical column $(4 \times 250 \mathrm{~mm})$ was used to separate the myo-inositol phosphates. They were detected after post-column reaction in a reactor coil with $1 \% \mathrm{Fe}\left(\mathrm{NO}_{3}\right)_{3} \cdot 9 \mathrm{H}_{2} \mathrm{O}$ in $0.33 \mathrm{M} \mathrm{HClO}_{4}$ according to the method of Phillippy and Bland ${ }^{62}$ (Flow rate $0.4 \mathrm{~mL} \mathrm{~min}^{-1}$ ), with UV detection $(290 \mathrm{~nm})$. Samples were prepared in DI water with a concentration of $500 \mathrm{mg} \mathrm{L}^{-1}$ and $10 \mu \mathrm{L}$ were injected. A gradient of A) $0.5 \mathrm{M} \mathrm{HCl}$ and B) $\mathrm{H}_{2} \mathrm{O}(18 \mathrm{M} \Omega * \mathrm{~cm}) ; 0-8 \min , 5-10 \% \mathrm{~A}, 95-90 \%$ B; 8-25 min, $10-35 \%$ A, $90-65 \%$ B; $25-35 \mathrm{~min}, 35-100 \%$ A, $65-0 \%$ B; $35-42 \mathrm{~min}$ $100 \% \mathrm{~A}, 0 \% \mathrm{~B} ; 42.1-50 \mathrm{~min}, 100-5 \%, 0-95 \% \mathrm{~B}$ (Flow rate $1 \mathrm{~mL} \mathrm{~min}^{-1}$ ) was used to separate the analytes.

For the measurements presented in Supplementary Fig. 3e, Ins $\mathrm{P}_{\mathrm{x}}$ were incubated for $8 \mathrm{~h}$ at $28^{\circ} \mathrm{C}$ in ammonium acetate buffer $(150 \mathrm{mM}$ ammonium acetate, adjusted with $\mathrm{NH}_{3}$ to $\mathrm{pH}$ 7). Samples were appropriately diluted and chromatographed on an HPLC system using a Pharmacia HR5/5 $(5 \mathrm{~cm})$ column and a gradient of $\mathrm{HCl}\left(0.005-0.5 \mathrm{M}\right.$; flow rate of $\left.1.0 \mathrm{~mL} \mathrm{~min}^{-1}\right)$. To achieve postcolumn derivatization, the eluents were mixed with $0.1 \mathrm{M} \mathrm{HCl}$ containing $5.18 \mathrm{mM}$ $\mathrm{FeCl}_{3}$ and $0.25 \mathrm{M} \mathrm{NaCl}$ via the twisted PTFE coil (length $8 \mathrm{~m}$; i.d. $0.5 \mathrm{~mm}$ ) (HPLC pump 2248, Pharmacia; flow rate of $0.8 \mathrm{~mL} \mathrm{~min}^{-1}$ ). A series of InsP $\mathrm{P}_{\mathrm{x}}$ standards was used to confirm the identity of the degradation products.

Extraction and HPLC analyses of yeast and $\boldsymbol{N}$. benthamiana. Inositol polyphosphate measurements were carried out with a $d d p 1 \Delta$ knockout yeast strain

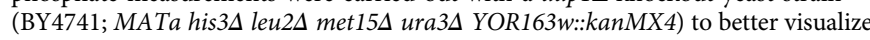
changes in myo-inositol pyrophosphates. The strain was generated by the Saccharomyces genome deletion project (http://www-sequence.stanford.edu/group/ yeast_deletion_project/deletions3.html) and obtained from Open Biosystems (GE Healthcare, Munich, Germany). Yeast transformants were grown to midlog phase in glucose-free minimal media supplemented with $3 \%$ raffinose and $6 \mu \mathrm{Ci} \mathrm{mL} L^{-1}$ $\left[{ }^{3} \mathrm{H}\right]-m y o$-inositol $\left(30-80 \mathrm{Ci} \mathrm{mmol}^{-1}\right.$; Biotrend; ART-0261-5), then induced for $3 \mathrm{~h}$ in minimal media containing $3 \%$ raffinose and $2 \%$ galactose. Cells were harvested, extracted, and analyzed by Partisphere SAX HPLC ${ }^{63}$. Inositol polyphosphate analyses with extracts of $N$. benthamiana transgenic lines were done as follows. 10 day-old seedlings grown in MS $2 \%$ solid sterile media were transferred into $3 \mathrm{~mL}$ liquid $0.5 \mathrm{MS}, 1 \%$ sucrose, pH 5.7 liquid media supplemented with $100 \mu \mathrm{Ci}\left[{ }^{3} \mathrm{H}\right]$ myo-inositol. The seedlings were labeled for a total of six days. In order to label adult leaves of $N$. benthamiana transgenic lines, leaves were cut from two-monthold plants grown in sterile conditions. The leaves were then kept in $3 \mathrm{~mL}$ liquid 0.5 MS, $1 \%$ sucrose, pH 5.7 liquid media supplemented with $100 \mu \mathrm{Ci}\left[{ }^{3} \mathrm{H}\right]-m y o$-inositol for six days. After labeling, the leaves were thoroughly washed in ultrapure water for two times before freeze harvesting into liquid $\mathrm{N}_{2}$. Inositol polyphosphates were extracted from the plant materials and resolved by SAX HPLC with the gradient of buffers A (1 mM EDTA) and B [1 mM EDTA and $1.3 \mathrm{M}\left(\mathrm{NH}_{4}\right)_{2} \mathrm{HPO}_{4}$, $\mathrm{pH} 3.8$, with $\left.\mathrm{H}_{3} \mathrm{PO}_{4}\right]^{29,63}$. The experiments were repeated three times independently with similar results. Due to a change in the Partisphere SAX column between runs, slight alterations in the elution times of inositol phosphates were observed.

XopH digestion of HPLC-purified $\left[{ }^{3} \mathbf{H}\right]$-myo-inositol phosphates. $\left[{ }^{3} \mathrm{H}\right]-\mathrm{InsP}_{6}$ and $\left[{ }^{3} \mathrm{H}\right]-$ InsP $_{5 c}$ were extracted and purified from SAX-HPLC runs of $\left[{ }^{3} \mathrm{H}\right]-m y o-$ inositol-labeled $g f p$ - and $x o p H$-expressing $N$. benthamiana seedlings using an anion exchange-based desalting protocol ${ }^{64}$, and subjected to $\mathrm{XopH}$ digestion as described above. XopH was inactivated by heating the reaction mixture at $95^{\circ} \mathrm{C}$ for $15 \mathrm{~min}$. 


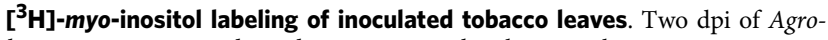
bacterium carrying indicated constructs, $N$. benthamiana leaves were cut into small pieces, placed in 6-well plates (Greiner) and washed two times with $5 \mathrm{~mL}$ of sterile ultra-pure water. The leaves were then transferred into $2 \mathrm{~mL}$ labeling media consisting of $0.5 \mathrm{MS}, 0.25 \%$ sucrose, $\mathrm{pH} 5.7,35 \mu \mathrm{Ci} \mathrm{mL}^{-1}$ of $\left[{ }^{3} \mathrm{H}\right]-$-myo-inositol (30 to $80 \mathrm{Ci} \mathrm{mmol}^{-1}$; Biotrend; ART-0261-5). The labeling was allowed to proceed for five days before harvesting. Neutralized extracts of tobacco leaves were then resolved by SAX-HPLC with the gradient of buffers A (1 mM EDTA) and B [1 mM EDTA and $1.3 \mathrm{M}\left(\mathrm{NH}_{4}\right)_{2} \mathrm{HPO}_{4}, \mathrm{pH} 3.8$, with $\left.\mathrm{H}_{3} \mathrm{PO}_{4}\right]^{29}$.

$\mathrm{TiO}_{2}$ bead pull down. Leaves of three different C. annuum cv. ECW or N. benthamiana plants were infected with $\mathrm{X} v \mathrm{v}$ as described above. Two dpi, three leaves per strain were harvested and frozen in liquid nitrogen. The samples were pooled and aliquoted to $130 \mathrm{mg}$ each for further analysis. One aliquot was used for protein extraction with buffer containing $50 \mathrm{mM}$ Tris- $\mathrm{HCl}, \mathrm{pH} 7.5,100 \mathrm{mM} \mathrm{NaCl}, 10 \mathrm{mM}$ imidazole, $10 \%(\mathrm{v} / \mathrm{v})$ glycerol, $0.1 \%(\mathrm{v} / \mathrm{v})$ Tween 20 and $5 \mathrm{mM} \beta$-mercaptoethanol, and analyzed by SDS-PAGE.

Another aliquot was subjected to $\mathrm{TiO}_{2}$ bead enrichment. $\mathrm{TiO}_{2}$ beads (Titansphere, $5 \mu \mathrm{m}$, GL Sciences) were prepared following the protocol by Wilson et al. ${ }^{65}$. Frozen plant material was homogenized using a mixer mill MM 400 (Retsch), resuspended in $0.5 \mathrm{~mL}$ ice-cold perchloric acid and kept on ice for $10 \mathrm{~min}$. After two centrifugation steps $\left(20,000 \times g, 10 \mathrm{~min}, 4^{\circ} \mathrm{C}\right)$ the supernatants were transferred into microfuge tubes containing $6 \mathrm{mg} \mathrm{TiO}$ beads each, mixed by brief vortexing and rotated $\left(4^{\circ} \mathrm{C}, 30 \mathrm{~min}\right)$. After centrifugation $\left(6000 \times g, 1 \mathrm{~min}, 4^{\circ} \mathrm{C}\right)$, the beads were washed twice with $0.5 \mathrm{~mL}$ ice-cold perchloric acid. Inositol polyphosphates were eluted by incubation with $0.2 \mathrm{~mL}$ of a $10 \%$ ammonia solution at RT for $5 \mathrm{~min}$ with intermediate brief vortexing. The beads were spun down $(6000 \times g, 1 \mathrm{~min})$ and supernatants removed into new tubes. The elution step was repeated yielding a final elution volume of $0.4 \mathrm{~mL}$. Eluted samples were vacuumdried, resuspended in $0.02 \mathrm{~mL}$ ultra-pure water and subjected to PAGE.

Metabolite profiling. For LC-ToF-MS analysis of myo-inositolpolyphosphates in recombinant $\mathrm{XopH}$ enzyme assays, $20 \mathrm{nmol} \mathrm{InsP}_{6}$ were incubated with $\mathrm{XopH}$ for 1 $\mathrm{h}$ at $28^{\circ} \mathrm{C}$. Non-targeted ion detection by LC-MS was achieved using an Acquity UPLC (Waters) and a TripleTOF 5600 mass spectrometer using the software Analyst 1.6 TF (Sciex, Toronto, Canada). Inositol phosphates were separated on a Nucleoshell RP18 $(150 \mathrm{~mm} \times 2 \mathrm{~mm} \times 2.7 \mu \mathrm{m}$, Macherey \& Nagel, Düren, Germany) by ion pairing chromatography using solvent A: $10 \mathrm{mM}$ tributyl amine (Sigma-Aldrich), which was acidified with glacial acetic acid to $\mathrm{pH} 6.2$ and solvent B: acetonitrile. Gradient (\% B): 0-2 min: 2, $18 \mathrm{~min}: 36,21 \mathrm{~min}: 95,22.5 \mathrm{~min}$ : 95, $22.52 \mathrm{~min}: 2,24 \mathrm{~min}: 2$, with a column flow of $400 \mu \mathrm{L} \mathrm{min}^{-1}$ and a column temperature of $40^{\circ} \mathrm{C}$.

Electrospray ionization was achieved in negative mode using a Duo-Source ${ }^{\mathrm{TM}}$ (Sciex, Toronto, Canada). Source temperature: $600^{\circ} \mathrm{C}$, ion spray voltage: $-4500 \mathrm{~V}$, surtain gas: $35 \mathrm{psi}$, source gases $1 / 2: 60 / 60 \mathrm{psi}$. ToF-MS ${ }^{1}$-mass features were assayed between 65 and $1250 \mathrm{Da}$ simultaneously with an array of non-targeted QToF-MS ${ }^{2}$ scan experiments in SWATH mode. During the latter, the transmission range for precursor ions in the Q1-quadrupol was set for $20 \mathrm{~ms}$ to mass windows of $33 \mathrm{Da}$ and was incremented from $m / z=65-1250 \mathrm{Da}$. The declustering potential was kept at $-35 \mathrm{~V}$, the collision energy was ramped between $-10,-45$, and $-60 \mathrm{~V}$ using the collision energy spread option. Mass accuracy (below $5 \mathrm{ppm}$ ) was automatically recalibrated every 20th measurement using the calibrant delivery system, APCI ionization (Duo-Source ${ }^{\mathrm{TM}}$ ) and the APCI calibrant mixture (all Sciex, Toronto, Canada). Simultaneous $\mathrm{MS}^{1}$-ToF scanning and SWATH-CID-fragmentation allowed for rapid assessment of $\mathrm{MS}^{1}$ and $\mathrm{MS}^{2}$ spectra with cycle times of $1 \mathrm{~s}$. The measurements were performed twice with independent samples giving similar results.

Data availability. The authors declare that all relevant data supporting the findings of this study are available within the paper and its supplementary information files or are available from the corresponding authors on request.

Received: 12 January 2017 Accepted: 13 November 2017

Published online: 18 December 2017

\section{References}

1. Büttner, D. Behind the lines-actions of bacterial type III effector proteins in plant cells. FEMS Microbiol. Rev. 40, 894-937 (2016).

2. Jones, J. B., Lacy, G. H., Bouzar, H., Stall, R. E. \& Schaad, N. W. Reclassification of the xanthomonads associated with bacterial spot disease of tomato and pepper. Syst. Appl. Microbiol. 27, 755-762 (2004).

3. Thieme, F. et al. Insights into genome plasticity and pathogenicity of the plant pathogenic bacterium Xanthomonas campestris pv. vesicatoria revealed by the complete genome sequence. J. Bacteriol. 187, 7254-7266 (2005).

4. Teper, D., Sunitha, S., Martin, G. B. \& Sessa, G. Five Xanthomonas type III effectors suppress cell death induced by components of immunity-associated MAP kinase cascades. Plant Signal. Behav. 10, e1064573 (2015).
5. Mur, L. A., Kenton, P., Lloyd, A. J., Ougham, H. \& Prats, E. The hypersensitive response; the centenary is upon us but how much do we know? J. Exp. Bot. 59, 501-520 (2008)

6. Boch, J. \& Bonas, U. Xanthomonas AvrBs3 family-type III effectors: discovery and function. Annu. Rev. Phytopathol. 48, 419-436 (2010).

7. Singer, A. U. et al. A pathogen type III effector with a novel E3 ubiquitin ligase architecture. PLoS Path. 9, el003121 (2013).

8. Cheong, M. S. et al. AvrBsT acetylates Arabidopsis ACIP1, a protein that associates with microtubules and is required for immunity. PLoS Path. 10, e1003952 (2014).

9. Potnis, N. et al. Avirulence proteins AvrBs7 from Xanthomonas gardneri and AvrBs1.1 from Xanthomonas euvesicatoria contribute to a novel gene-for-gene interaction in pepper. Mol. Plant Microbe Interact. 25, 307-320 (2012).

10. Tabernero, L., Aricescu, A. R., Jones, E. Y. \& Szedlacsek, S. E. Protein tyrosine phosphatases: structure-function relationships. FEBS J. 275, 867-882 (2008).

11. Kay, B. K., Williamson, M. P. \& Sudol, M. The importance of being proline: the interaction of proline-rich motifs in signaling proteins with their cognate domains. FASEB J. 14, 231-241 (2000).

12. Lim, K. L., Lai, D. S. Y., Kalousek, M. B., Wang, Y. \& Pallen, C. J. Kinetic analysis of two closely related receptor-like protein-tyrosine-phosphatases, PTPalpha and PTPepsilon. Eur. J. Biochem. 245, 693-700 (1997).

13. Zhang, Z. Y., Maclean, D., Thiemesefler, A. M., Roeske, R. W. \& Dixon, J. E. A continuous spectrophotometric and fluorometric assay for protein-tyrosine phosphatase using phosphotyrosine-containing peptides. Anal. Biochem. 211, 7-15 (1993).

14. Kelley, L. A., Mezulis, S., Yates, C. M., Wass, M. N. \& Sternberg, M. J. The Phyre2 web portal for protein modeling, prediction and analysis. Nat. Protoc. 10, 845-858 (2015).

15. Chu, H.-M. et al. Structures of Selenomonas ruminantium phytase in complex with persulfated phytate: DSP phytase fold and mechanism for sequential substrate hydrolysis. Structure 12, 2015-2024 (2004).

16. Raboy, V. myo-Inositol-1,2,3,4,5,6-hexakisphosphate. Phytochemistry 64, 1033-1043 (2003).

17. Murphy, A. M., Otto, B., Brearley, C. A., Carr, J. P. \& Hanke, D. E. A role for inositol hexakisphosphate in the maintenance of basal resistance to plant pathogens. Plant J. 56, 638-652 (2008).

18. Laha, D. et al. Inositol polyphosphate binding specificity of the jasmonate receptor complex. Plant Physiol. 171, 2364-2370 (2016).

19. Popov, G., Fraiture, M., Brunner, F. \& Sessa, G. Multiple Xanthomonas euvesicatoria type III effectors inhibit flg22-triggered immunity. Mol. Plant Microbe Interact. 29, 651-660 (2016)

20. Greiner, R. \& Konietzny, U. in Enzymes in Farm Animal Nutrition 2nd edn, (eds Bedford, M. \& Patridge, G.) 96-128 (CAB International, Wallingford, UK 2010).

21. Konietzny, U. \& Greiner, R. Molecular and catalytic properties of phytatedegrading enzymes (phytases). Int. J. Food Sci. Technol. 37, 791-812 (2002).

22. Puhl, A. A. et al. Kinetic and structural analysis of a bacterial protein tyrosine phosphatase-like myo-inositol polyphosphatase. Protein Sci. 16, 1368-1378 (2007).

23. Yang, L. et al. Expedited selection of NMR chiral solvating agents for determination of enantiopurity. ACS Cent. Sci. 2, 332-340 (2016).

24. Li, Y. \& Raushel, F. M. Differentiation of chiral phosphorus enantiomers by ${ }^{31} \mathrm{P}$ and ${ }^{1} \mathrm{H}$ NMR spectroscopy using amino acid derivatives as chemical solvating agents. Tetrahedron 18, 1391-1397 (2007).

25. Moon, R. B. \& Richards, J. H. Determination of intracellular $\mathrm{pH}$ by ${ }^{31} \mathrm{P}$ magnetic resonance. J. Biol. Chem. 248, 7276-7278 (1973).

26. Adlung, N. et al. Non-host resistance induced by the Xanthomonas effector XopQ is widespread within the genus Nicotiana and functionally depends on EDS1. Front. Plant Sci. 7, 1796 (2016).

27. Sheard, L. B. et al. Jasmonate perception by inositol-phosphate-potentiated COI1-JAZ co-receptor. Nature 468, 400-405 (2010).

28. Tan, X., Calderon-Villalobos, L. I. A., Sharon, M. \& Zheng, C. Mechanism of auxin perception by the TIR1 ubiquitin ligase. Nature 446, 640-645 (2007).

29. Laha, D. et al. VIH2 regulates the synthesis of inositol pyrophosphate $\mathrm{InsP}_{8}$ and jasmonate-dependent defenses in Arabidopsis. Plant Cell 27, 1082-1097 (2015).

30. Shoji, T. \& Hashimoto, T. Tobacco MYC2 regulates jasmonate-inducible nicotine biosynthesis genes directly and by way of the NIC2-locus ERF genes. Plant Cell Physiol. 52, 1117-1130 (2011).

31. Kiba, A. et al. SEC14 phospholipid transfer protein is involved in lipid signaling-mediated plant immune responses in Nicotiana benthamiana. PLoS ONE 9, e98150 (2014).

32. Adie, B., Chico, J., Rubio-Somoza, I. \& Solano, R. Modulation of plant defenses by ethylene. J. Plant Growth Regul. 26, 160-177 (2007).

33. Donnell, P., Calvert, C., Atzorn, R. \& Wasternack, C. Ethylene as a signal mediating the wound response of tomato plants. Science 274, 1914-1917 (1996).

34. Zhu, Z. \& Lee, B. Friends or foes: new insights in jasmonate and ethylene co-actions. Plant Cell Physiol. 56, 414-420 (2015). 
35. Xie, D. X., Feys, B. F., James, S., Nieto-Rostro, M. \& Turner, J. G. COI1: an Arabidopsis gene required for jasmonate-regulated defense and fertility. Science 280, 1091-1094 (1998).

36. Macho, A. P. et al. A bacterial tyrosine phosphatase inhibits plant pattern recognition receptor activation. Science 343, 1509-1512 (2014).

37. Chatterjee, S., Sankaranarayanan, R. \& Sonti, R. V. PhyA, a secreted protein of Xanthomonas oryzae pv. oryzae, is required for optimum virulence and growth on phytic acid as a sole phosphate source. Mol. Plant Microbe Interact. 16, 973-982 (2003).

38. Lund, S. T., Stall, R. E. \& Klee, H. J. Ethylene regulates the susceptible response to pathogen infection in tomato. Plant Cell 10,371-382 (1998).

39. Weber, S. et al. A type IV translocated Legionella cysteine phytase counteracts intracellular growth restriction by phytate. J. Biol. Chem. 289, 34175-34188 (2014).

40. Stephens, L. R. et al. myo-inositol pentakisphosphates. Structure, biological occurrence and phosphorylation to myo-inositol hexakisphosphate. Biochem. J. 275, 485-499 (1991)

41. Bertani, G. Studies on lysogenesis. I. The mode of phage liberation by lysogenic Escherichia coli. J. Bacteriol. 62, 293-300 (1951).

42. Van Larebeke, N. et al. Large plasmid in Agrobacterium tumefaciens essential for crown gall-inducing ability. Nature 252, 169-170 (1974).

43. Daniels, M. J. et al. Cloning of genes involved in pathogenicity of Xanthomonas campestris pv. campestris using the broad host range cosmid pLAFR1. EMBO J. 3, 3323-3328 (1984)

44. Figurski, D. \& Helinski, D. R. Replication of an origin-containing derivative of plasmid RK2 is dependent on a plasmid function provided in trans. Proc. Natl Acad. Sci. USA 76, 1648-1652 (1979).

45. Huguet, E., Hahn, K., Wengelnik, K. \& Bonas, U. hpaA mutants of Xanthomonas campestris pv. vesicatoria are affected in pathogenicity but retain the ability to induce host-specific hypersensitive reaction. Mol. Microbiol. 29, 1379-1390 (1998).

46. Walhout, A. J. M. et al. GATEWAY recombinational cloning: application to the cloning of large numbers of open reading frames or ORFeomes. Method Enzymol. 328, 575-592 (2000).

47. Nakagawa, T. et al. Development of series of gateway binary vectors, pGWBs, for realizing efficient construction of fusion genes for plant transformation. J. Biosci. Bioeng. 104, 34-41 (2007).

48. Nakagawa, T., Ishiguro, S. \& Kimura, T. Gateway vectors for plant transformation. Plant Biotechnol. 26, 275-284 (2009).

49. Lorenz, C., Hausner, J. \& Büttner, D. HrcQ provides a docking site for early and late type III secretion substrates from Xanthomonas. PLoS ONE 7, e51063 (2012).

50. Römer, P. et al. Plant-pathogen recognition mediated by promoter activation of the pepper Bs3 resistance gene. Science 318, 645-648 (2007).

51. Liu, Y., Schiff, M., Marathe, R. \& Dinesh-Kumar, S. P. Tobacco Rar1, EDS1 and NPR1/NIM1 like genes are required for $N$-mediated resistance to tobacco mosaic virus. Plant J. 30, 415-429 (2002).

52. Tsugama, D., Liu, S. \& Takano, T. A rapid chemical method for lysing Arabidopsis cells for protein analysis. Plant Methods 7, 22 (2011).

53. Voinnet, O., Rivas, S., Mestre, P. \& Baulcombe, D. An enhanced transient expression system in plants based on suppression of gene silencing by the p19 protein of tomato bushy stunt virus. Plant J. 33, 949-956 (2003).

54. Chomczynski, P. \& Sacchi, N. Single-step method of RNA isolation by acid guanidinium thiocyanate-phenol-chloroform extraction. Anal. Biochem. 162, 156-159 (1987).

55. Gasteiger, E. et al. in Protein Identification and Analysis Tools on the ExPASy Server 571-607 (Springer, New York, 2005).

56. Schaaf, G., Betts, L., Garrett, T. A., Raetz, C. R. H. \& Bankaitis, V. A. Crystallization and preliminary X-ray diffraction analysis of phospholipidbound Sfh1p, a member of the Saccharomyces cerevisiae Sec14p-like phosphatidylinositol transfer protein family. Acta Crystallogr. F Struct. Biol. Cryst. Commun. 62, 1156-1160 (2006).

57. Blom, N., Gammeltoft, S. \& Brunak, S. Sequence and structure-based prediction of eukaryotic protein phosphorylation sites. J. Mol. Biol. 294, 1351-1362 (1999).

58. Hornbeck, P. V., Chabra, I., Kornhauser, J. M., Skrzypek, E. \& Zhang, B. PhosphoSite: a bioinformatics resource dedicated to physiological protein phosphorylation. Proteomics 4, 1551-1561 (2004).

59. Diella, F., Gould, C. M., Chica, C., Via, A. \& Gibson, T. J. Phospho. ELM: a database of phosphorylation sites-update 2008. Nucleic Acids Res. 36, D240-D244 (2008).

60. Frank, R. Spot-synthesis: an easy technique for the positionally addressable, parallel chemical synthesis on a membrane support. Tetrahedron 48, 9217-9232 (1992).
61. Pavlovic, I. et al. Prometabolites of 5-diphospho-myo-inositol pentakisphosphate. Angew. Chem. Int. Ed. Engl. 54, 9622-9626 (2015).

62. Phillippy, B. Q. \& Bland, J. M. Gradient ion chromatography of inositol phosphates. Anal. Biochem. 175, 162-166 (1988).

63. Azevedo, C. \& Saiardi, A. Extraction and analysis of soluble inositol polyphosphates from yeast. Nat. Protoc. 1, 2416-2422 (2006).

64. Azevedo, C., Burton, A., Bennett, M., Onnebo, S. M. N. \& Saiardi, A. Synthesis of $\mathrm{InsP}_{7}$ by the inositol hexakisphosphate kinase 1 (IP6K1). Methods Mol. Biol. 645, 73-85 (2010).

65. Wilson, M. S., Bulley, S. J., Pisani, F., Irvine, R. F. \& Saiardi, A. A novel method for the purification of inositol phosphates from biological samples reveals that no phytate is present in human plasma or urine. Open Biol. 5, 150014 (2015).

66. Tommaso, P. et al. T-Coffee: a web server for the multiple sequence alignment of protein and RNA sequences using structural information and homology extension. Nucleic Acids Res. 39, W13-W17 (2011).

67. Hofmann, K. \& Baron, M. BOXSHADE Version 3.21. (Bioinformatics Group, Lausanne, Switzerland, 1996).

68. Delano, W. L. The PyMOL Molecular Graphics System (DeLano Scientific, Palo Alto, CA, USA, 2002).

69. Stevenson-Paulik, J., Bastidas, R. J., Chiou, S.-T., Frye, R. A. \& York, J. D. Generation of phytate-free seeds in Arabidopsis through disruption of inositol polyphosphate kinases. Proc. Natl Acad. Sci. USA 102, 12612-12617 (2005).

\section{Acknowledgements}

We thank K. Pflüger, N. Bauer, L. Bigler, C. Brancato, H. Espenhahn, P. Gaugler, A Henning, P. Johnen, C. Kretschmer, C. Liechti, N. F. Rebollo, and B. Rosinsky for technical assistance. This work was funded by grants from the Bundesministerium für Bildung und Forschung ("tools, targets \& therapeutics - ProNet-T3" to U.B. and J.L.), the Deutsche Forschungsgemeinschaft (SFB 648/TP A1 and B1 to U.B. and J.L., Gottfried Wilhelm Leibniz Prize to U.B., SFB 1101/TP A05 and research grant SCHA 1274/4-1 to G.S.), the Swiss National Science Foundation (PP00P2_157607 to H.J.), and the CarlZeiss Stiftung (to H.J.). Publication was supported by the Open Access Publication Fund of the Martin-Luther-University Halle-Wittenberg. We thank the NMR facilities of UZH and Uni Freiburg (Magres) for extended measurement time.

\section{Author contributions}

D.B., D.L., U.B., G.S., H.J., S.W., S.T., M.S. and G.B. developed the concept and designed the experiments. D.B., D.L., A.H., L.E., A.M., G.B., I.P., S.T., O.N., A.S., R.H., J.W. and N. P. performed the experiments and analyzed the data. R.G., A.T. and J.L. gave technical support and conceptual advice. S.T., G.S., H.J., U.B., M.S., D.L. and D.B. wrote the manuscript.

\section{Additional information}

Supplementary Information accompanies this paper at https://doi.org/10.1038/s41467017-02195-8.

Competing interests: The authors declare no competing financial interests.

Reprints and permission information is available online at http://npg.nature.com/ reprintsandpermissions/

Publisher's note: Springer Nature remains neutral with regard to jurisdictional claims in published maps and institutional affiliations.

Open Access This article is licensed under a Creative Commons Attribution 4.0 International License, which permits use, sharing, adaptation, distribution and reproduction in any medium or format, as long as you give appropriate credit to the original author(s) and the source, provide a link to the Creative Commons license, and indicate if changes were made. The images or other third party material in this article are included in the article's Creative Commons license, unless indicated otherwise in a credit line to the material. If material is not included in the article's Creative Commons license and your intended use is not permitted by statutory regulation or exceeds the permitted use, you will need to obtain permission directly from the copyright holder. To view a copy of this license, visit http://creativecommons.org/ licenses/by/4.0/

(c) The Author(s) 2017 